\title{
Novel interaction between neurotrophic factor-a1/carboxypeptidase E and serotonin receptor, 5-HTR1E, protects human neurons against oxidative/neuroexcitotoxic stress via $\beta$-arrestin/ERK signaling
}

\author{
Vinay Kumar Sharma ${ }^{1} \cdot$ Xuyu Yang ${ }^{1} \cdot$ Soo-Kyung Kim ${ }^{2} \cdot$ Amirhossein Mafi $^{2} \cdot$ Daniel Saiz-Sanchez ${ }^{3}$. \\ Patricia Villanueva-Anguita ${ }^{3} \cdot$ Lan Xiao $^{1} \cdot$ Leila Toulabi $^{1} \cdot$ Asuka Inoue $^{4} \cdot$ William A. Goddard $~_{\mathrm{III}}{ }^{2} \cdot$ Y. Peng Loh $^{1}$ (i)
}

Received: 26 July 2021 / Revised: 14 October 2021 / Accepted: 1 November 2021 / Published online: 29 December 2021

This is a U.S. government work and not under copyright protection in the U.S.; foreign copyright protection may apply 2021

\begin{abstract}
Protecting neurons from death during oxidative and neuroexcitotoxic stress is key for preventing cognitive dysfunction. We uncovered a novel neuroprotective mechanism involving interaction between neurotrophic factor- $\alpha 1$ (NF- $\alpha 1 /$ carboxypeptidase E, CPE) and human 5-HTR1E, a G protein-coupled serotonin receptor with no previously known neurological function. Co-immunoprecipitation and pull-down assays confirmed interaction between NF $\alpha 1 / \mathrm{CPE}$ and 5-HTR1E and ${ }^{125} \mathrm{I}$

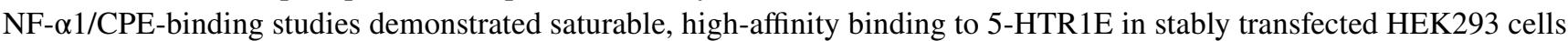
$(\mathrm{Kd}=13.82 \mathrm{nM})$. Treatment of 5-HTR1E stable cells with NF- $\alpha 1 / C P E$ increased pERK $1 / 2$ and pCREB levels which prevented a decrease in pro-survival protein, BCL2, during $\mathrm{H}_{2} \mathrm{O}_{2}$-induced oxidative stress. Cell survival assay in $\beta$-arrestin Knockout HEK293 cells showed that the NF- $\alpha 1 /$ CPE-5-HTR1E-mediated protection against oxidative stress was $\beta$-arrestindependent. Molecular dynamics studies revealed that NF- $\alpha 1 / \mathrm{CPE}$ interacts with 5-HTR1E via 3 salt bridges, stabilized by several hydrogen bonds, independent of the serotonin pocket. Furthermore, after phosphorylating the C-terminal tail and intracellular loop 3 (ICL3) of NF- $\alpha 1 / C P E-5-H T R 1 E$, it recruited $\beta$-arrestin1 by forming numerous salt bridges and hydrogen bonds to ICL2 and ICL3, leading to activation of $\beta$-arrestin1. Immunofluorescence studies showed 5-HTR1E and NF- $\alpha 1 /$ CPE are highly expressed and co-localized on cell surface of human hippocampal neurons. Importantly, knock-down of 5 -HTR1E in human primary neurons diminished the NF- $\alpha 1 / \mathrm{CPE}$-mediated protection of these neurons against oxidative stress and glutamate neurotoxicity-induced cell death. Thus, NF- $\alpha 1 / \mathrm{CPE}$ uniquely interacts with serotonin receptor 5-HTR1E to activate the $\beta$-arrestin/ERK/CREB/BCL2 pathway to mediate stress-induced neuroprotection.
\end{abstract}

Keywords GPCR $\cdot \beta$-arrestin $\cdot$ Cytotoxicity $\cdot$ Neuroprotection

Soo-Kyung Kim, Amirhossein Mafi and Daniel Saiz-Sanchez have contributed equally.

William A. Goddard III

wag@caltech.edu; wagoddard3@gmail.com

Y. Peng Loh

lohp@mail.nih.gov

1 Section on Cellular Neurobiology, Eunice Kennedy Shriver National Institute of Child Health and Human Development, National Institutes of Health, 49, Convent Drive, Bldg 49, Rm 6A-10, Bethesda, MD 20892, USA

\section{Introduction}

Understanding mechanisms that can protect against neuronal cell death caused by various types of stress, such as neuroexcitotoxicity and oxidative stress, in the brain will facilitate the development of therapeutics that can mitigate these challenges. Indeed, many growth and trophic factors, such

2 Materials and Process Simulation Center, California Institute of Technology, Pasedena, CA 91125, USA

3 Neuroplasticity and Neurodegeneration Laboratory, Medical School, Regional Center for Biomedical Research, University of Castilla-La Mancha, 13071 Ciudad Real, Spain

4 Graduate School of Pharmaceutical Sciences, Tohoku University, Sendai, Miyagi 980-8578, Japan 
as transforming growth factors (TGFs), insulin-like growth factor (IGFs), epidermal growth factor (EGF), fibroblast growth factor 2 (FGF2) and brain-derived neurotrophic factor (BDNF), are known to play a role in neuroprotection [1-3]. Recently, we have identified a new trophin, neurotrophic factor- $\alpha 1(\mathrm{NF}-\alpha 1)$, which is critical in protecting hippocampal neurons against stress-induced cell death in mice [4]. Interestingly, NF- $\alpha 1$ was originally characterized as carboxypeptidase $\mathrm{E}$ (CPE), a pro-hormone-processing enzyme, [5, 6], but our studies demonstrated that its multiple trophic functions are independent of its enzyme activity $[4,7]$. NF- $\alpha 1 / \mathrm{CPE}$ knock-out (KO) mice showed complete degeneration of hippocampal CA3 neurons, and cognitive dysfunction after emotional and physical stress, despite the expression of normal levels of BDNF and other growth factors in the hippocampus $[4,8]$. In other studies, rats subjected to global ischemia revealed sustained increase in NF- $\alpha 1 / C P E$ expression in the hippocampal CA 3 neurons, facilitating the survival of these neurons [9]. A mouse model of a human cpe gene mutation found in an Alzheimer's disease (AD) patient showed hippocampal neuronal degeneration and memory loss [10]. Moreover, genetic studies identified null and non-sense mutations in the cpe gene in five families with a total of 8 members having homozygous mutations, presented clinical features of obesity, diabetes and learning disabilities [11-13]. Thus, NF- $\alpha 1 / \mathrm{CPE}$ plays important trophic roles in neuronal cell survival and cognitive function in vivo [7].

Cell biological studies provided additional evidence that NF- $\alpha 1 / \mathrm{CPE}$ promotes cell survival. NF- $\alpha 1 / \mathrm{CPE}$ applied extracellularly protected rat hippocampal primary neurons against $\mathrm{H}_{2} \mathrm{O}_{2}$-induced cytotoxicity by activating ERK and AKT signaling cascades, which increased pro-survival protein, BCL2 and decreased caspase-3 activation [14, 15]. In murine skeletal stem cells, treatment with NF- $\alpha 1 / \mathrm{CPE}$ activated ERK signaling and increased proliferation [16]. However, the mechanism of action of extracellular NF- $\alpha 1 /$ $\mathrm{CPE}$ in neuroprotection remains elusive.

We hypothesized that NF- $\alpha 1 / \mathrm{CPE}$ action is mediated via interaction with a cell surface receptor, and employed a high-throughput screening strategy using NF- $\alpha 1 / \mathrm{CPE}$ as a ligand against a library of 324 human G protein-coupled receptors (GPCRs) to identify a receptor. Only one of them, 5-hydroxytryptamine receptor 1-E (5-HTR1E), a Gi-coupled receptor showed a strong positive signal. 5-HTR1E is a member of the serotonin receptor family which is located to human chromosome 6q14-q15 [17] and is expressed in humans, monkeys and guinea pig, but not in rats or mice [18-21]. Pharmacological and immunocytochemical localization studies in the guinea pig brain indicate that 5-HTR1E is abundant in the hippocampus, frontal cortex, and olfactory bulb, but with no known function in brain [21, 22]. Recently, Qin et al. [23] reported that 5-HTR1E signaling may prevent the chronic psychological stress-promoted progression of ovarian cancer and might have potential therapeutic value.

Here we carried out co-immunoprecipitation and pulldown studies to show interaction between NF- $\alpha 1 / \mathrm{CPE}$ and 5 -HTR1E, and radiolabeled NF- $\alpha 1 / C P E-b i n d i n g ~ e x p e r i-$ ments to determine the binding affinity to 5-HTR1E. We used molecular dynamics (MD) methods to predict the binding site of NF- $\alpha 1 / \mathrm{CPE}$ to 5 -HTR1E. Studies were also conducted on 5-HTR1E-transfected HEK293 cells as a model to determine the signal transduction cascade activated by the NF- $\alpha 1 / \mathrm{CPE}-5-\mathrm{HTR} 1 \mathrm{E}$ interaction to mediate cell survival during oxidative stress. The co-expression and neuronal surface membrane co-localization of NF- $\alpha 1 / \mathrm{CPE}$ and 5-HTR1E in human hippocampus was mapped by immunohistochemistry. Finally, the effect of 5-HTR1E knockdown in human primary neurons, on neuroprotection was investigated. Our experimental and computational findings indicate that NF- $\alpha 1 / \mathrm{CPE}$ interacts with 5-HTR1E in a novel manner, independent of the serotonin pocket, to promote survival of neurons and other human cells via $\beta$-arrestin recruitment and activation of pERK-CREB-BCL2 signaling pathway.

\section{Materials and methods}

\section{Cells}

HTLA cells were purchased from Add gene, USA. HEK293 cells stably expressing 5-HTR1E were obtained from Dr. Bryan Roth's laboratory at University of North Carolina (UNC). HEK293, U118 and LN18 glioblastoma cells were purchased from ATCC (Manassas, VA). Human brain primary neurons (cat. no. 1520) and extract (cat. no. 1526) were purchased from ScienCell Research Laboratories, Carlsbad, CA.

\section{Recombinant NF-a1/CPE}

Recombinant mouse NF- $\alpha 1 / \mathrm{CPE}(53 \mathrm{kDa})$ was customsynthesized and highly purified by GenScript, NJ, USA [4]. Mouse NF- $\alpha 1 / \mathrm{CPE}$ protein (uniport id:Q00493) sequence is 96.6\% homologous to human (uniport id:P16870).

\section{DNA constructs}

Plasmids expressing human wild type and truncated fragments of NF- $\alpha 1 / \mathrm{CPE}$ (residues 1-150, 1-350, 351-476) with a C-terminal V5 tag were constructed into pcDNA 3.1 backbone by GenScript (GenScript, NJ, USA). Plasmid expressing human 5-HTR1E with a C-terminal Myc tag was from Origene (Rockville, MD). 


\section{Western blot}

Cells were lysed in RIPA (cat. No. 89901) or Pierce TM IP Lysis Buffer (cat. No. 87787), Thermo scientific, USA. Proteins were quantified using BCA or Bradford assay and separated on SDS-PAGE gel followed by western blotting. Protein bands were visualized and quantified by the Odyssey infrared imaging system and software (LI-COR Inc, Lincoln, $\mathrm{NE})$.

\section{Luciferase assay for 5-HTR1E receptor}

The PRESTO-Tango GPCR assay kit and HTLA cells were purchased from Addgene. This assay is based on the 'transcriptional activation following arrestin translocation' (TANGO). Upon activation by ligand molecules, GPCR recruits $\beta$-arrestin2-TEV fusion protein (stably expressing in HTLA cells) to the V2 tail which is present in the same plasmid followed by a TEV cleavage site and tTA transcription factor. Cleavage at the GPCR-TEV protein site releases the tTA, which, after transport to the nucleus, activates tTA-dependent luciferase reporter gene (see Suppl. Fig. S1) [23]. HTLA cells $(10,000$ cells/well) were plated in a white 96-well plate in DMEM supplemented with $10 \%$ FBS. On the next day, $0.2 \mu \mathrm{g} / \mathrm{well} 5$-HTR1E or control plasmid was transfected in serum-free media. Renila luciferase was also transfected as internal control. After $48 \mathrm{~h}$ of transfection, cells were treated with different doses of recombinant $\mathrm{NF}-\alpha 1 / \mathrm{CPE}(0-100 \mathrm{nM})$ or 5 -HT $(0-1 \mu \mathrm{M})$ for $3 \mathrm{~h}$. Luciferase assay was performed using Dual-Luciferase ${ }^{\circledR}$ Reporter Assay System (Cat. No. E1910, Promega, USA), according to manufacturer's protocols. Luminescence was measured using a Synergy HTX plate reader (Biotech, USA).

\section{Radioligand-binding studies}

For binding experiments, custom-labeled $\left[{ }^{125} \mathrm{I}\right] \mathrm{NF}-\alpha 1 / \mathrm{CPE}$ (PerkinElmer, USA) was used to bind 5-HTR1E stable or control HEK293 cells. These cells $(\sim 200,000)$ were collected in $5 \mathrm{ml}$ polystyrene tubes and washed three times with serum-free binding medium (DMEM) and incubated with different concentrations $(1.25-30 \mathrm{nM}$, triplicates for each data point) of $\left[{ }^{125} \mathrm{I}\right] \mathrm{NF}-\alpha 1 / \mathrm{CPE}$ (hot) in $1 \mathrm{ml}$ serum-free binding medium for $3 \mathrm{~h}$. on ice. $500 \mathrm{nM}$ unlabeled NF- $\alpha 1 /$ $\mathrm{CPE}$ protein (cold) or carboxypeptidase $\mathrm{B}$ (porcine pancreas CPB, Sigma Aldrich, USA) was also incubated for non-specific binding and displacement experiments. After incubation, cells were washed four times with cold PBS ( $2 \mathrm{ml}$ each time) and counted in a Perkin Elmer gamma-counter. For displacement and specificity experiments, cells were incubated with $30 \mathrm{nM}\left[{ }^{125} \mathrm{I}\right] \mathrm{NF}-\alpha 1 / \mathrm{CPE}$ in the presence and absence of $500 \mathrm{nM}$ cold NF- $\alpha 1 / \mathrm{CPE}$ or CPB, (a negative control protein for NF- $\alpha 1 / \mathrm{CPE})$.

\section{Co-immunoprecipitation}

NF- $\alpha 1 / C P E-p o s i t i v e ~ L N-18$ cells were lysed in immunoprecipitation lysis buffer $(50 \mathrm{mmol} / \mathrm{L}$ Tris-HCL, $150 \mathrm{mmol} / \mathrm{L}$ $\mathrm{NaCl}, 5 \mathrm{mmol} / \mathrm{L}$ EDTA, 0.5\% NP-40) supplemented with proteinase inhibitor cocktail (Sigma-Aldrich) and cleared by centrifugation at $12,000 \times g$ for $20 \mathrm{~min}$ at $4^{\circ} \mathrm{C}$. A total of $1 \mathrm{mg}$ protein of precleared cell lysates was incubated with $4 \mu \mathrm{g}$ of anti-5-HTR1E polyclonal antibodies (Abcam) or anti-NF- $\alpha 1 / \mathrm{CPE}$ monoclonal antibody (BD Bioscience) and rotated at $4{ }^{\circ} \mathrm{C}$ overnight. The immuno-complexes were recovered by incubation with $30 \mu \mathrm{l}$ of $50 \%$ of protein A/GSepharose slurry (Santa Cruz) at $4^{\circ} \mathrm{C}$ overnight. The pellets were washed 4 times with IP lysis buffer and the bound proteins were eluted in loading buffer at $65^{\circ} \mathrm{C}$ for $5 \mathrm{~min}$. and subjected to immunoblotting analyses using an anti-NF- $\alpha 1 /$ CPE or anti-5-HTR1E antibody.

\section{Pull-down assay}

A series of vectors for expressing NF- $\alpha 1 / \mathrm{CPE}$ and truncated fragments of NF- $\alpha 1 / \mathrm{CPE}$ (residues 1-150, 1-350, 351-476) with a C-terminal V5 tag were constructed into pcDNA3.1 vector for pull-down assay. Unlike the other two truncated fragments CPE1-150 and CPE 1-350, truncated fragment CPE 351-476 has no signal peptide. All constructs were verified by DNA sequencing. For pull-down assay, HEK293 cells were co-transfected with a combination of plasmids expressing 5-HTR1E-myc (Origene), and CPE or its derivatives with V5 tag using Lipofectamine 2000 for $48 \mathrm{~h}$. Transfected cells were harvested and lysed with immunoprecipitation lysis buffer. $1 \mathrm{mg}$ protein of each total cell lysate was incubated with $20 \mu \mathrm{l}$ of anti-Myc or anti-V5-conjugated agarose (Santa Cruz) overnight at $4^{\circ} \mathrm{C}$. Pellets were washed 4 times with lysis buffer and the bound proteins were eluted in LDS loading buffer (Invitrogen) at $65^{\circ} \mathrm{C}$ for $5 \mathrm{~min}$. and subjected to immunoblotting analysis with anti-V5 antibody (Invitrogen) or anti-Myc antibody (Santa Cruz).

\section{Molecular docking of NF-a1/CPE with 5-HTR1E}

In order to predict which NF- $\alpha 1 / \mathrm{CPE}$ residues bind to 5-HTR1E surface residues, both NF- $\alpha 1 / \mathrm{CPE}$ and 5-HTR1E structures were predicted using available templates in the PDB database. We then used these structures to predict the binding site for CPE. The detailed methodology is in the Supplementary methods S1.

\section{Molecular dynamics simulation of $\beta$-arrestin with 5-HTR1E}

For detailed methodology, see Supplementary methods S2. 


\section{ERK phosphorylation}

5-HTR1E stable and HEK293 control cells were seeded in 12 -well plate $\left(1 \times 10^{5} /\right.$ well $)$ in complete DMEM media and incubated overnight at $37^{\circ} \mathrm{C}$ in a $\mathrm{CO}_{2}$ incubator. $\beta$-arrestin knockout cells were generated and characterized as previously described (2) and control HEK293 cells were transfected with 5-HTR1E plasmid for $48 \mathrm{~h}$. On the next day, media were changed to serum-free medium (SFM) and after $3 \mathrm{~h}$, cells were treated with different concentrations $(0-50 \mathrm{nM})$ of NF- $\alpha 1 / \mathrm{CPE}$ or $(0-1 \mu \mathrm{M}) 5$-HT for 5-10 min. For inhibitor studies, control and 5-HTR1E-expressing HEK293 cells were treated with $1 \mu \mathrm{m}$ FR900359 for $30 \mathrm{~min}$ or $200 \mathrm{ng}$ PTX for $4 \mathrm{~h}$ prior to treatment with $50 \mathrm{nM} \mathrm{NF- \alpha 1}$. Change in pERK was assessed by probing the western blot membranes with pERK1/2 (Thr202/Tyr204) rabbit antibody (1:5000, Cell signaling, Danvers, MA) and tERK1/2 mouse monoclonal antibody (1:5000, Cell signaling, Danvers, MA) simultaneously. Fluorescence-labeled anti-rabbit $(800 \mathrm{~nm})$ and anti-mouse $(680 \mathrm{~nm})$ secondary antibodies (1:5000) were used to visualize the protein bands. pERK was normalized with tERK, and fold changes were calculated from three independent experiments after densitometric analysis using image J software, NIH.

\section{CREB phosphorylation}

5 -HTR1E stable cells were seeded in 12 -well plate $\left(1 \times 10^{5} \%\right.$ well) in complete DMEM. On the next day, after media were changed to SFM for $3 \mathrm{~h}$, cells were treated with $50 \mathrm{nM}$ NF- $\alpha 1 / \mathrm{CPE}$ at different time points (10-60 min). For the control experiments, HEK293 cells were also treated with $50 \mathrm{nM}$ NF- $\alpha 1 / \mathrm{CPE}$. Effect of 5-HT on CREB phosphorylation was analyzed by treating 5-HTR1E stable cells with $1 \mu \mathrm{M} 5$-HT in the presence and absence of $10 \mu \mathrm{M}$ forskolin. Changes in pCREB levels were assessed by Western blot using pCREB rabbit mAb against Ser133 (Cat. No. \#9198, Cell signaling, Danvers, MA) and tCREB mouse mAb (Cat. No. \#9104, Cell signaling, Danvers, MA) for loading control.

\section{cAMP assay}

cAMP assay was performed in 5-HTR1E stable cells. 5000 cells/well were seeded in a 96-well plate in complete DMEM overnight. On the next day, media were replaced with SFM for $3 \mathrm{~h}$. These cells were treated with $10 \mu \mathrm{M}$ forskolin (an activator of adenylyl cyclase enzyme to raise cAMP levels) in the presence of phosphodiesterase inhibitor (Cat. no. 524718, set I-Calbiochem, Sigma Aldrich, USA) for $10 \mathrm{~min}$ followed by $1 \mu \mathrm{M}$ 5-HT, BRL54443 (5-HTR1E/F agonist), or $50 \mathrm{nM} \mathrm{NF-} \alpha 1 / \mathrm{CPE}$ for $20 \mathrm{~min}$. To check the synergistic effect, 5-HTR1E-expressing cells were also treated with a combination of $1 \mu \mathrm{M} 5-\mathrm{HT}$ and $50 \mathrm{nM} \mathrm{NF-} \alpha 1 / \mathrm{CPE}$. cAMP assay was performed using cAMP-Glo ${ }^{\mathrm{TM}}$ Assay (Promega, USA) according to manufacturer's instructions. Luminescence was recorded on plate reader. All experiments were performed in triplicate and repeated at least three times.

\section{BCL2 protein expression}

5-HTR1E stable cells and HEK293 control cells were seeded in a 12-well plate. A day later, cells were treated with $50 \mathrm{nM}$ recombinant NF- $\alpha 1 / \mathrm{CPE}$ protein or $1 \mu \mathrm{M} 5$-HT in serumfree medium for $6 \mathrm{~h}$ followed by $200 \mu \mathrm{M} \mathrm{H}_{2} \mathrm{O}_{2}$ for overnight. BCL2 expression was analyzed by western blot using BCL2 antibody (rabbit, Cell signaling, USA).

\section{Lactate dehydrogenase assay}

HEK293 cells were transfected with 5-HTR1E plasmid or empty control vector for $48 \mathrm{~h}$ using Lipofectamine 2000 reagent kit (Invitrogen, Carlsbad, CA). While $\beta$-arrestin KO and their control HEK293 cells (10,000 cells per well) were infected with Ad-5-HTR1E or control Ad-LacZ (Vector Biolabs) at $10 \mathrm{MOI}$, for $48 \mathrm{~h}$. These cells were treated with $50 \mathrm{nM}$ CPE overnight followed by $300 \mu \mathrm{M} \mathrm{H}_{2} \mathrm{O}_{2}$ for $6 \mathrm{~h}$. Human primary neurons were seeded in 96-well, poly-D-lysine-coated plates at a density of 13,000 neurons/well in neuronal medium (Cat. \#1521, ScienCell Research Laboratories, Carlsbad, CA) and cultured until they were attached to the plate. The neurons were then infected with Ad-5-HTR1E shRNA or Ad-LacZ (Vector Biolabs) at $30 \mathrm{MOI}$, for $72 \mathrm{~h}$ and then overnight treatment with $50 \mathrm{nM} \mathrm{CPE}$. The medium was replaced with neuronal medium without growth factors and the neurons challenged with $100 \mu \mathrm{M} \mathrm{H}_{2} \mathrm{O}_{2}$ for $6 \mathrm{~h}$ or $40 \mu \mathrm{M}$ glutamate (Sigma-Aldrich, St. Louis, MO) for $24 \mathrm{~h}$. Cytotoxicity was measured by the amount of LDH released using a CytoTox 96 assay kit (Promega, USA).

\section{Immunofluorescence and immunohistochemistry of human hippocampus}

Distribution of 5-HTR1E and NF- $\alpha 1 / C P E$ in the hippocampus of six human postmortem brain tissues (without neuropathology) was assessed by immunofluorescence and immunohistochemistry experiments. Brain tissues were obtained from three national brain banks, Barcelona IDIBAPS, Murcia BIOBANC-MUR and Madrid BTCIEN, Spain. For detailed methods, see supplementary methods $\mathrm{S} 3$.

\section{Statistical analysis}

Data are representative of at least 3 separate experiments $(\mathrm{N})$, with each experiment performed in triplicate. Data were analyzed by 2-tailed Student's $t$ test or 1-way ANOVA, 
followed by Tukey's post hoc multiple comparisons tests, were noted. Statistical significance was defined as $p<0.05$.

\section{Results}

\section{NF-a1/CPE interacts with 5-HTR1E serotonin receptor}

High-throughput screening of NF- $\alpha 1 / \mathrm{CPE}$ against a GPCR library was performed using the $\beta$-arrestin biased PRESTOTango assay, discovering 5-HTR1E as a potential target receptor for further study (Suppl. Fig. S1) [24]. To verify that NF- $\alpha 1 / C P E$ binds 5-HTR1E, HTLA cells expressing 5-HTR1E receptor were treated with different doses of recombinant NF- $\alpha 1 / \mathrm{CPE}$ or its known ligand serotonin. $\mathrm{NF}-\alpha 1 / \mathrm{CPE}$ activated 5 -HTR1E in the luciferase assay (see methods) within $3 \mathrm{~h}$ of treatment and optimally with 10-25 nM doses (Fig. 1a1) while serotonin (5-HT) saturated the receptor between 1 and $10 \mathrm{nM}$ concentration (Fig. 1a2).

To determine if NF- $\alpha 1 / \mathrm{CPE}$ binds to 5-HTR1E on the cell surface membrane, we performed radioligand-binding assays. 5-HTR1E stable cells were incubated with $\left[{ }^{125} \mathrm{I}\right]$ NF- $\alpha 1 / C P E$ (hot), with or without non-radiolabeled NF- $\alpha 1 /$ CPE (cold), to compete with the hot NF- $\alpha 1 / \mathrm{CPE}$ binding. A decrease in total bound ${ }^{125} \mathrm{INF}-\alpha 1 / \mathrm{CPE}$ was observed in the presence of cold NF- $\alpha 1 / \mathrm{CPE}$, showing competition and specific binding of hot NF- $\alpha 1 / \mathrm{CPE}$ (Fig. 1b1), while there was no displacement in total $\left[{ }^{125} \mathrm{I}\right] \mathrm{NF}-\alpha 1 / \mathrm{CPE}$ bound when Carboxypeptidase B (CPB) was added with [ $\left.{ }^{125} \mathrm{I}\right] \mathrm{NF}-\alpha 1 /$ $\mathrm{CPE}$, verifying specificity of the binding. Saturation-binding experiments were also performed using various concentrations of $\left[{ }^{125} \mathrm{I}\right] \mathrm{NF}-\alpha 1 / \mathrm{CPE}$ (Fig. 1b2) with and without cold NF- $\alpha 1 / C P E$. Specific binding was obtained by subtracting non-specific binding from total binding (Fig. 1b3). Saturation-binding data were analyzed by non-linear regression analysis using the GraphPad PRISM 8.0 program. The best fit Kd value was $13.82 \mathrm{nM}$ for ${ }^{125}$ I NF- $\alpha 1 /$ CPE. Similar experiments were performed in control HEK293 cells. A small amount of other cell surface binding was observed (Fig. 1 b4 and Suppl. Fig. S2). These results indicate that NF- $\alpha 1 / \mathrm{CPE}$ binds specifically and with high affinity to 5-HTR1E on cell surface.

\section{NF-a1/CPE interacts with 5-HTR1E via specific molecular domains}

To verify that NF- $\alpha 1 / \mathrm{CPE}-5$-HTR $1 \mathrm{E}$ interaction occurs with these endogenous proteins in mammalian cells, we carried out co-immunoprecipitation experiments in a human glioblastoma cell line, $\mathrm{LN}-18$, that expresses high levels of endogenous 5-HTR1E protein. Interaction between NF- $\alpha 1 /$ CPE and 5-HTR1E proteins was detected in these LN-18 cell extracts, (Fig. 1c1 and c2). To demonstrate interactions between NF- $\alpha 1 / \mathrm{CPE}$ and 5-HTR1E and then to identify the NF- $\alpha 1 / \mathrm{CPE}-$ binding domains required for NF- $\alpha 1 / \mathrm{CPE}-$ 5-HTR1E interaction, we constructed a series of vectors expressing full-length and truncated fragments of NF- $\alpha 1$ / CPE (residues 1-150, 1-350, 351-476) with a C-terminal V5 tag and 5-HTR1E-myc, which were transfected into HEK293 cells for pull-down assays. All the fragments were well expressed and detected in the lysates (Fig. 1e). Fulllength NF- $\alpha 1 / \mathrm{CPE}$ (Fig. 1d), as well as NF- $\alpha 1 / \mathrm{CPE}$ fragment 1-350 (Fig. 1e) showed strong binding to 5-HTR1E, whereas binding of the other fragments (1-150, 351-476, Fig. 1e) was not detected. The results indicate that the middle region of NF- $\alpha 1 / \mathrm{CPE}$ (amino acids 150-350) harbors a binding motif(s) for 5-HTR1E (Fig. 1e).

\section{Molecular docking and molecular dynamics studies predict strong interactions between NF-a1/CPE and the extracellular loops of 5-HTR1E}

To predict the molecular interaction of NF- $\alpha 1 / \mathrm{CPE}$ with 5 -HTR1E, we first generated the 3D structure of NF- $\alpha 1 / \mathrm{CPE}$ using homology modeling. To predict the transmembrane domain structure of 5-HTR1E, we applied our GEnSeMBLE complete sampling procedure to predict the pre-activated conformation of 5-HTR1E, and then we added loops using a homology strategy. Leveraging our biochemical binding assays in Fig. 1e, we used our DarwinDock techniques and molecular dynamics (MD) to construct initial structures for the interaction between NF- $\alpha 1 / \mathrm{CPE}$ (residues 151-350) and 5-HTR1E (extracellular portion). See supplementary information (SI, methods section, results SK1-SK2 and Fig. SK1-SK4). Fig. SK4 shows the total, electrostatic and van der Waals (vdW) interaction energies of 5-HTR1E and $\mathrm{NF}-\alpha 1 / \mathrm{CPE}$ through $100 \mathrm{~ns}$ MD trajectories. Until $5 \mathrm{~ns}$, $4 \mathrm{SBs}$ in the complex were constrained. After $5 \mathrm{~ns}$, the structure was relaxed without any constraints. The initial minimized structure of 5-HTR $1 \mathrm{E}$ and NF- $\alpha 1 / \mathrm{CPE}$ complex shows interactions between the positive-charged residues in the ECL and negative-charged residues in NF- $\alpha 1 / \mathrm{CPE}$.

This was followed by $1.5 \mu$ s of MD which led to the strong salt bridge (SB) interactions between 5-HTR1E and NF- $\alpha 1 / C P E$ shown in Fig. 2. Our MD simulations show that the NF- $\alpha 1 / \mathrm{CPE}$ couples strongly to the extracellular loops (ECL) of 5-HTR1E (Fig. 2a), which may block the path for other small molecules to penetrate the orthosteric binding pocket. Our MD studies find that NF- $\alpha 1 /$ CPE forms polar interactions with the extracellular portion of 5-HTR1E (Fig. 2b). In particular, salt bridges: K302D86 ${ }^{\mathrm{ECL} 1}$, D306-K89 ${ }^{\mathrm{ECL} 1}$, D275-R165 ${ }^{\mathrm{ECL} 2}$, hydrogen bonds: D259- R164 ${ }^{\mathrm{ECL} 2}$, E260-S162 ${ }^{\mathrm{ECL} 2}$, and an aromatic interaction between W319-W160 ${ }^{\mathrm{ECL} 2}$ participate in strong coupling between NF- $\alpha 1 / \mathrm{CPE}$ and 5 -HTR1E. We found that 


\section{(a1)}

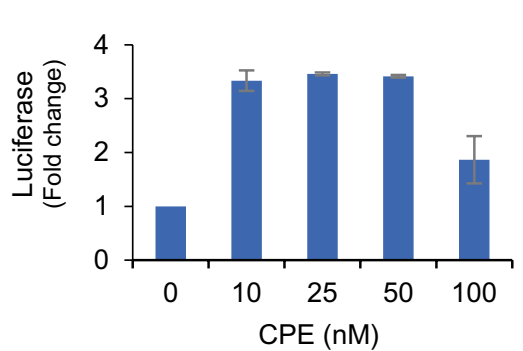

(b2)

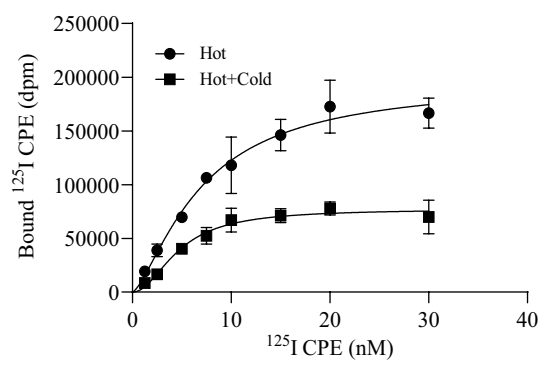

(a2)

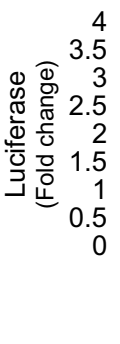

(b3)

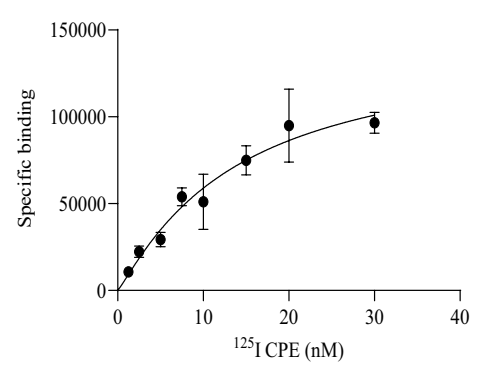

(b1)

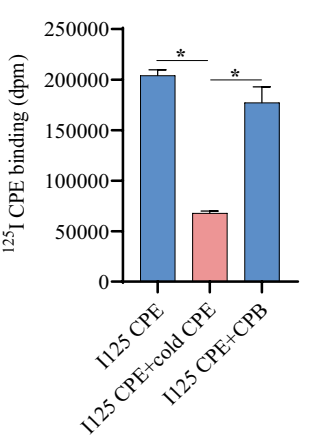

(b4)

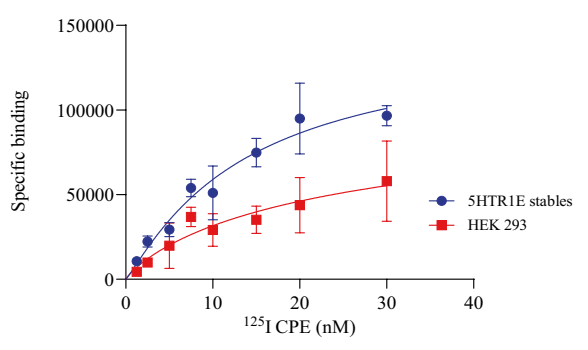

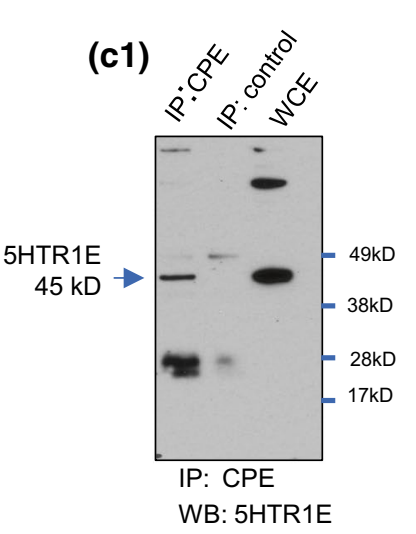

(d)

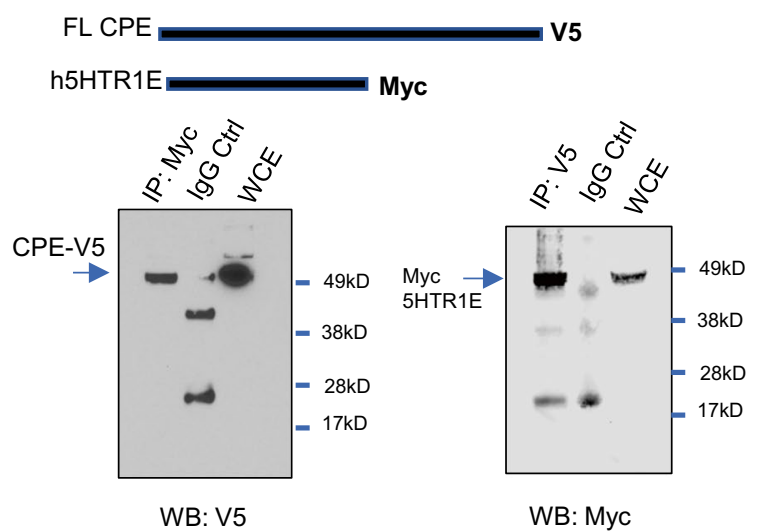

the orthosteric serotonin-binding pocket of 5-HTR1E was stabilized through a salt bridge between the protonated nitrogen and $\mathrm{D} 102^{3.32}$ and an $\mathrm{H}$ bond between $\mathrm{NH}$ and $\mathrm{E} 311^{6.55}$, as shown in Fig. 2c.

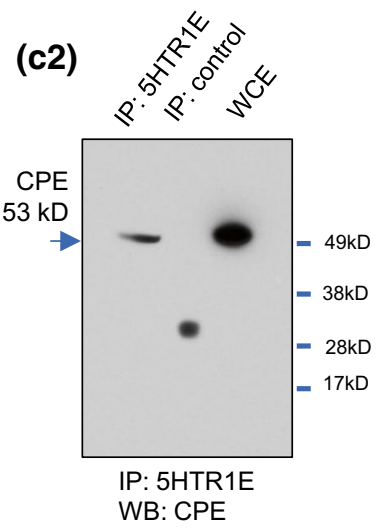

(e)

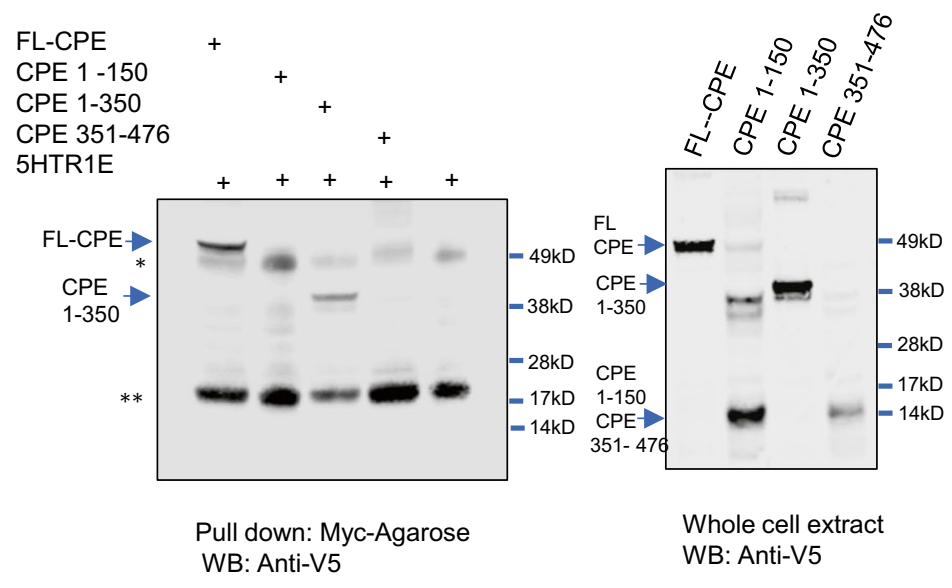

Our MD studies find that binding NF- $\alpha 1 / \mathrm{CPE}$ stabilizes the active-state conformation of 5-HTR1E, featuring an expanded intracellular region (Fig. 5e). The outward movement of the cytosolic end of TM6 from TM3 is the hallmark of class A GPCR activation [25]. However, a polar 
4Fig. 1 a Luciferase assay. HTLA cells were transfected with 5-HTR1E plasmid for $48 \mathrm{~h}$ and dose dependent effect of a1 CPE and $\mathbf{a} 2$ 5-HT (serotonin) were checked by dual luciferase assay after $3 \mathrm{~h}$ of treatment. Results are expressed as fold change, values are mean $\pm \mathrm{SD}, n=3, N=2$. CPE binds to 5-HTR1E on the cell surface. b ${ }^{125}$ I CPE binding to 5-HTR1E stable cells. b1 5-HTR1E stable cells were incubated with $30 \mathrm{nM}^{125} \mathrm{I}$ radiolabeled CPE (hot) for $3 \mathrm{~h}$ on ice in serum-free binding medium. To demonstrate binding specificity, $500 \mathrm{nM}$ non-radio-labeled CPE (cold) or CPB was co-incubated with the hot CPE to compete and displace the hot CPE binding. The bar graphs show that the ${ }^{125}$ I CPE binding to 5-HTR1E was displaced by cold CPE but not by CPB. One-way ANOVA analysis followed by Tukey's post hoc multiple comparison test, $[F$ $(2,6)=169, p<0.0001]$, For ${ }^{125} \mathrm{I} \mathrm{CPE}+$ cold CPE compared to ${ }^{125} \mathrm{I}$ CPE, $* p<0.0001,{ }^{125} \mathrm{I} \mathrm{CPE}+$ cold CPE compared to ${ }^{125} \mathrm{I} \mathrm{CPE}+$ cold $\mathrm{CPB}, * p<0.0001$, values are mean $\pm \mathrm{SD}, n=3$. b2-3 ${ }^{125} \mathrm{I}$ CPE binds to 5-HTR1E in a saturable manner. 5-HTR1E stable cells were incubated with different concentrations $(1.25-30 \mathrm{nM})$ of ${ }^{125} \mathrm{I}$ CPE (hot) with or without $500 \mathrm{nM}$ cold CPE for $3 \mathrm{~h}$ on ice in serum-free binding medium. The specific binding and $\mathrm{K}_{\mathrm{d}}$ were determined by measuring bound ${ }^{125} \mathrm{I}$ CPE in the presence of $500 \mathrm{nM}$ cold CPE. (B4) Comparison of ${ }^{125}$ I CPE binding between 5-HTR1E stable and control HEK293 cells. c Co-immunoprecipitation experiments. Extracts from LN-18 cells were immunoprecipitated (IP) using 5-HTR1E or CPE antibodies followed by immunoblotting with anti-CPE (c1) or anti-5-HTR1E (c2); the arrowhead indicates co-precipitated CPE and 5-HTR1E protein bands. Total cell lysate (WCE) was used as positive control, normal rabbit or mouse serum (IP Ctrl) was used as IP control. d Pull-down experiments. HEK293 cells were co-transfected with V5-CPE and Myc-5-HTR1E. Pull-down assays were carried out by incubating cell extracts with anti-V5 and anti-Myc-conjugated agarose overnight and pellets were analyzed by immunoblotting with anti-V5 antibody or anti-Myc antibody, respectively. Left panel: pull-down with anti-myc and probed with anti-V5, arrow shows CPEV5; Right panel: pull-down with anti-V5 and probed with anti-myc, arrow shows myc-5-HTR1E. e Analysis of CPE domains binding to 5-HTR1E. Top: schematic representation of constructs expressing CPE and its derivatives with V5 tag and 5-HTR1E with Myc tag. Middle, full-length CPE (1-476) or truncated CPE fragments with V5 tag was co-transfected with 5-HTR1E with Myc tag in HEK293 cells, transfected cells were harvested and lysed. Pull-down assay was carried out by incubating cell extracts with Myc-conjugated agarose, and pellets were analyzed by immunoblotting with anti-V5 antibody. Bottom: expression of CPE and its derivatives in transiently transfected HEK293 cells. Note that only CPE-1-350 was pulled down

lock between conserved residues R $120^{3.50}$ [the superscript is Ballesteros-Weinstein numbering for GPCRs [26], taken from Ref. [27] and E268 ${ }^{6.30}$ in the inactive-state serotonin receptor [28], impedes TM6 from the outward displacement associated with normal $\mathrm{G}$ protein activation. Disruption of this polar lock is crucial for GPCR activation [29-31] and subsequent recruitment of downstream effectors. To examine if NF- $\alpha 1 / \mathrm{CPE}$ binding stabilizes the active-state conformation of 5-HTR1E, we examined the distance between TM3 and TM6 (Fig. 5c). Our analysis indicates that the cytoplasmic region of 5-HTR 1E remains fully open with an average distance of $\sim 18.1 \pm 0.1 \AA$ [measuring the distance between $\left.\mathrm{R} 120^{3.50}(\mathrm{CZ})-\mathrm{E} 268^{6.30}(\mathrm{CD})\right]$, compared to $\sim 6 \AA$ for the crystallographic inactive 5- $\mathrm{HT}_{2 \mathrm{~A}}$ receptor [28].
5-HTR1E-NF-a1/CPE interaction activates ERK/CREB pathway

NF- $\alpha 1 / C P E$ has been shown to activate ERK signaling in hippocampal neurons [14]. To determine if NF- $\alpha 1 / C P E$ activates the ERK pathway via 5-HTR1E, we treated 5-HTR1E stable or control HEK293 cells with $0-50 \mathrm{nM} \mathrm{NF-} \alpha 1 / \mathrm{CPE}$ for 5-15 min and assayed for ERK phosphorylation. A significant increase (3.4-fold) in phosphorylation of ERK 1/2 was observed in 5-HTR1E stable cells treated with $50 \mathrm{nM}$ NF- $\alpha 1 / C P E$ between 5 and 10 min (Fig. 3a), but not in control, HEK293 cells (Suppl. Fig. S3, panel a1-2). To determine if serotonin could also activate the ERK signaling pathway via 5-HTR1E receptor, we treated 5-HTR1E stable cells with $0 \mathrm{nM}$ to $1 \mu \mathrm{M} 5$-HT for 5-15 min. We found that at a high dose of $1 \mu \mathrm{M}, 5$-HT increased ERK 1/2 phosphorylation 2.5-fold (Fig. 3b). Control HEK293 cells were also treated with $0-1 \mu \mathrm{M} 5$-HT in similar manner but did not show any significant increase in ERK1/2 phosphorylation (Suppl. Fig. S3, panel b1-2).

Since CREB is a downstream effector of ERK signaling pathways and its phosphorylation is positively related to cell survival against oxidative stress and regulation of pro-survival protein BCL2 [32,33], we analyzed the effect of NF- $\alpha 1 / C P E$ on CREB phosphorylation. 5-HTR1E stable or control HEK293 cells were treated with $50 \mathrm{nM} \mathrm{NF- \alpha 1/}$ CPE and change in pCREB was assessed by Western blotting. After 20 min of treatment, an increase (1.3-fold) in CREB phosphorylation was observed in 5-HTR1E stable cells (Fig. 3d) but not in control HEK293 cells (Suppl. Fig. $\mathrm{S} 3$, panel $\mathrm{c} 1-2)$. These results show that NF- $\alpha 1 / \mathrm{CPE}$ can increase CREB phosphorylation via 5-HTR1E interaction.

\section{5-HTR1E-NF-a1/CPE interaction does not inhibit CAMP pathway}

5-HTR1E is a Gi-linked receptor that reduces cyclic AMP via inhibition of adenyl cyclase. To determine the effect of NF- $\alpha 1 / C P E$ alone and in combination with $5-\mathrm{HT}$ on cAMP, we treated 5-HTR1E stable cells with $50 \mathrm{nM} \mathrm{NF- \alpha 1/CPE} \mathrm{or}$ $1 \mu \mathrm{M} 5-\mathrm{HT}$ or both, in the presence of forskolin. Our results show that NF- $\alpha 1 / \mathrm{CPE}-$ treated cells alone or in combination with 5-HT did not affect cAMP levels, while 5-HT and BRL 54,443 , a 5-HTR1E agonist reduced the level of cAMP $44 \%$ and $66 \%$, respectively (Fig. 3d1, d2). These results indicate that NF- $\alpha 1 /$ CPE-5-HTR1E function is not linked to the classical 5-HTR1E signaling mechanism which maintains an efficient Gi protein-coupling profile for 5-HT-induced cyclic AMP signaling. 
Fig. 2 High-affinity CPE-5HTR1E coupling. a The side view of binding interface between CPE and 5-HTR1E in the presence of $\beta$-arrestin1 (omitted for clarity) resulted from $\sim 1.5 \mu \mathrm{s}$ MD simulations colored by subunits: CPE (pink), 5-HTR1E (green). b Tight coupling between the CPE and the extracellular surface of 5-HTR1E, mostly involving the polar interactions between the pair proteins. c The orthosteric serotonin-binding pocket was stabilized through salt bridge between the protonated nitrogen and D102 (3.32) and H-bonding between $\mathrm{NH}$ and E311 (6.55)

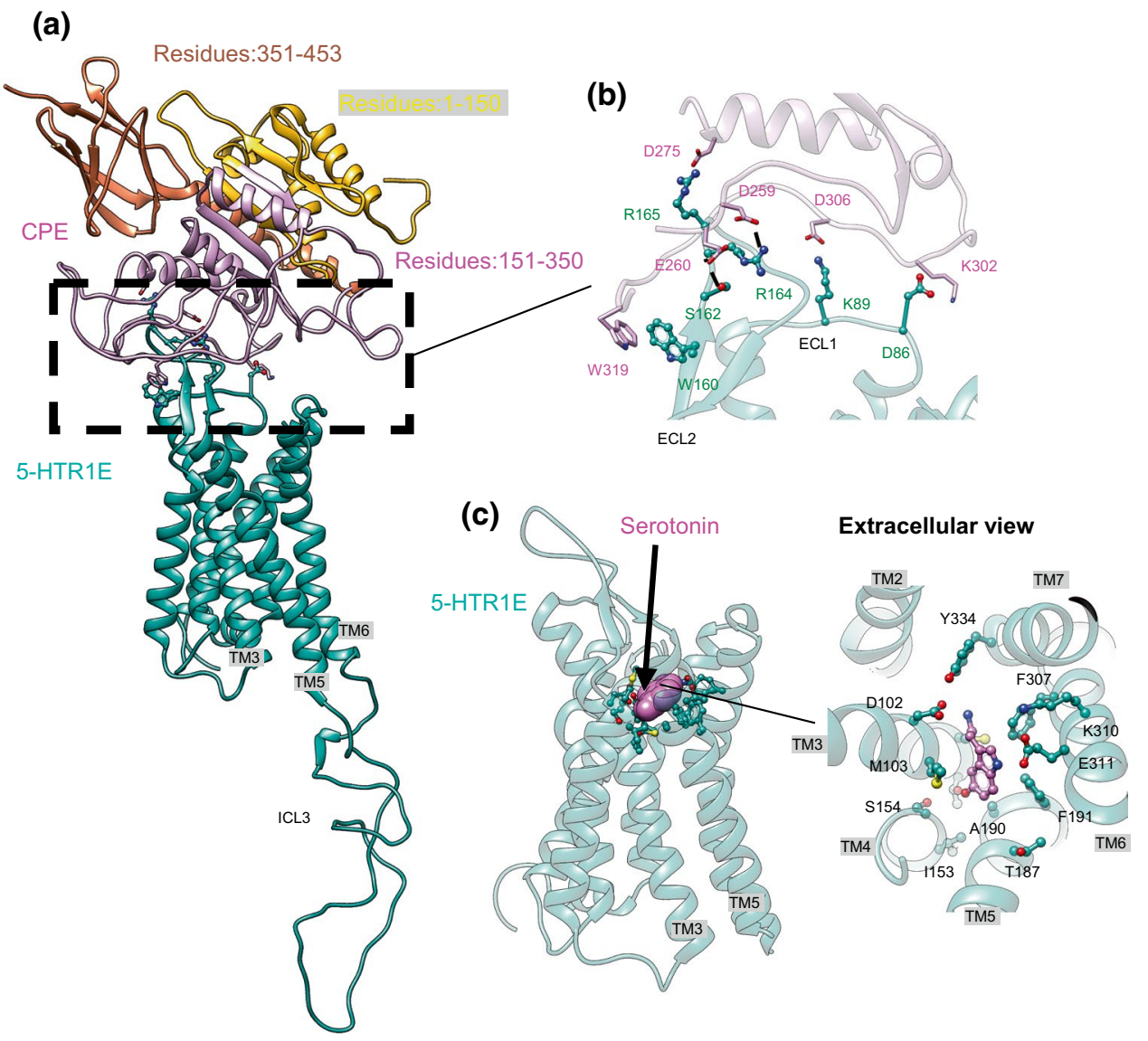

\section{5-HTR1E-mediated ERK signaling is independent of $\mathrm{Gq}$ or Gi proteins}

To further explore whether the mechanism through which NF- $\alpha 1 / C P E$ activates ERK phosphorylation in 5-HTR1Eexpressing cells involves Gi proteins, we tested the effect of Gi inhibitor PTX and Gq inhibitor FR900359 [34] on NF- $\alpha 1$-activated ERK phosphorylation. After $4 \mathrm{~h}$ incubation with or without PTX, cells were treated with $50 \mathrm{nM}$ NF- $\alpha 1$ and compared with cells not treated with PTX. Figure 3, panel e1-2 shows that there was no significant difference in pERK1/2 phosphorylation between PTX-treated and -untreated groups. Figure $3 \mathrm{f} 1-2$ shows that after treatment with $50 \mathrm{nM} \mathrm{NF-} \alpha 1$, pERK1/2 level increased slightly in FR900359-pretreated cells. These results show that Gi inhibitor PTX and Gq inhibitor FR900359 did not inhibit NF- $\alpha 1$ activation of ERK phosphorylation.

\section{5-HTR1E mediates ERK phosphorylation and cell survival via $\beta$-arrestin recruitment}

For some GPCRs, ERK signal transduction pathway can be activated via $\beta$-arrestin recruitment. We therefore determined if NF- $\alpha 1 /$ CPE-induced ERK $1 / 2$ phosphorylation by 5 -HTR1E is dependent on $\beta$-arrestin. Figure $4 \mathrm{~b} 1-2$ showed the increase in ERK 1/2 phosphorylation in 5-HTR1E-transfected HEK293 cells was abolished in 5-HTR1E-transfected $\beta$-arrestin KO HEK293 cells (Fig. 4a1-2). These data indicate that $\beta$-arrestin plays a role in 5-HTR1E-mediated ERK phosphorylation.

Previously, NF- $\alpha 1 / \mathrm{CPE}$ was shown to up-regulate prosurvival BCL2 protein expression in hippocampal neurons with $\mathrm{H}_{2} \mathrm{O}_{2}$-induced oxidative stress [14]. Here we determined if such an effect can occur because of interaction between NF- $\alpha 1 / \mathrm{CPE}$ and 5-HTR1E. 5-HTR1E stable cells were treated with $50 \mathrm{nM} \mathrm{NF- \alpha 1/CPE}$ for $6 \mathrm{~h}$ followed by $200 \mu \mathrm{M} \mathrm{H}_{2} \mathrm{O}_{2}$ treatment overnight. $\sim 52 \%$ reduction in the mitochondrial pro-survival BCL2 protein level was observed after $\mathrm{H}_{2} \mathrm{O}_{2}$ treatment in 5-HTR1E stable cells, which was prevented by NF- $\alpha 1 / \mathrm{CPE}$ treatment (Fig. $4 \mathrm{c} 1-2)$ but not by serotonin (Suppl. Fig S4). These experiments were also done in control HEK293 cells, but no effect was observed (Fig. 4d1-2). We then showed that pretreatment with NF- $\alpha 1 /$ CPE effectively decreased the $\mathrm{H}_{2} \mathrm{O}_{2}$-induced cytotoxicity in 5-HTR1E expressing cells compared with BSA control. In contrast, HEK293 cells transfected with vector control, pretreatment with $\mathrm{NF}-\alpha 1 / \mathrm{CPE}$ did not decrease cytotoxicity when challenged with $\mathrm{H}_{2} \mathrm{O}_{2}$ (Fig. 4e). To determine if $\beta$-arrestin recruitment is involved in 5-HTR1E-mediated protection against $\mathrm{H}_{2} \mathrm{O}_{2}$-induced cytotoxicity, the experiments 
(a1)

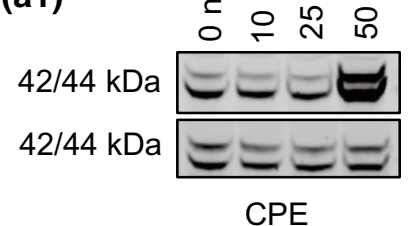

(a2)

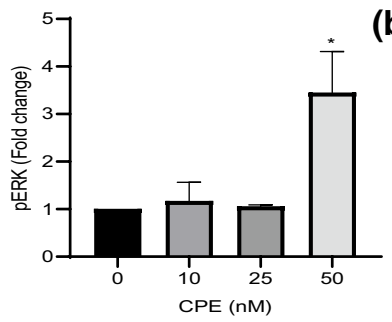

(d1)

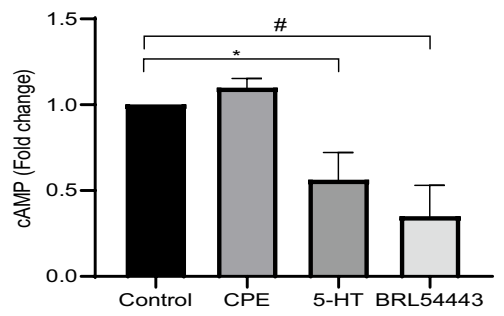

(e1)

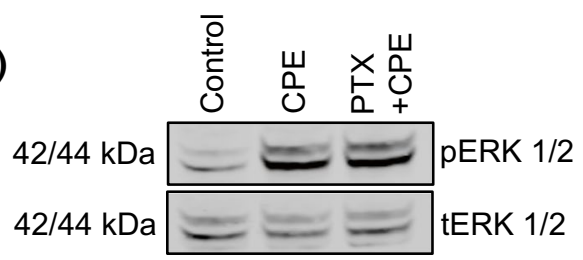

(e2)

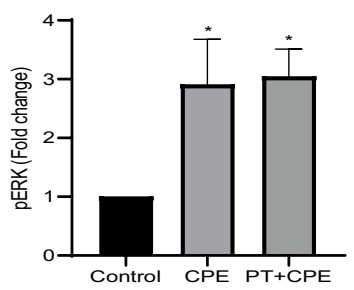

Fig. 3 a-c CPE activates ERK signaling in HEK293 cells via interaction with 5-HTR1E. HEK293 cells stably transfected with 5-HTR1E were treated with 0-50 nM CPE (a1-2) or $0 \mathrm{nM}$ to $1 \mu \mathrm{M}$ 5-HT (b12) for 5-15 $\mathrm{min}$ and pERK $1 / 2$ were analyzed by Western blotting. Bar graphs showing the fold change in pERK1/2 after normalization with tERK1/2 as an internal control. $N=3$, One-way ANOVA analysis followed by Tukey's post hoc multiple comparison test, $[F(3,8)=18.60, * p=0.0006], * p=0.0011$ for $50 \mathrm{nM}$ CPE when compared to untreated control and $[F(3,8)=28.18, * p=0.0001]$, ${ }^{*} p=0.0001$ for $1 \mu \mathrm{M} 5$-HT when compared to untreated control, values are mean $\pm \mathrm{SD}, N=3$. HEK293 control cells were also treated with CPE or 5-HT. One-way ANOVA analysis followed by Tukey's post hoc multiple comparison test, $p>0.05$ (ns), $N=3$ (Suppl. Fig. 3A-B). c CPE increases CREB phosphorylation in 5-HTR1E stable cells. 5-HTR1E stable cells (c1-2) and control HEK293 cells (Suppl. Fig. 3, c1-2) were treated with $50 \mathrm{nM} \mathrm{CPE}$ for different time points (between 10 and $60 \mathrm{~min}$ ) and analyzed by Western blotting. Bar graphs showing the fold change in pCREB after normalization with tCREB as an internal control. Student's $t$ test $* * * p<0.0001$ for $50 \mathrm{nM}$ CPE when compared to untreated control, values are

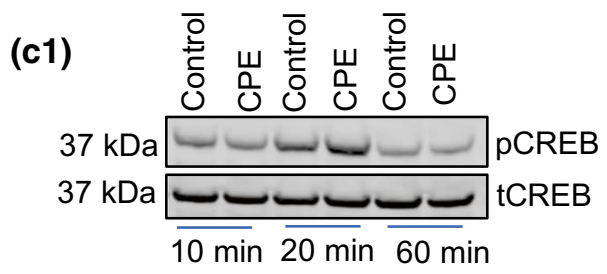

(c2)

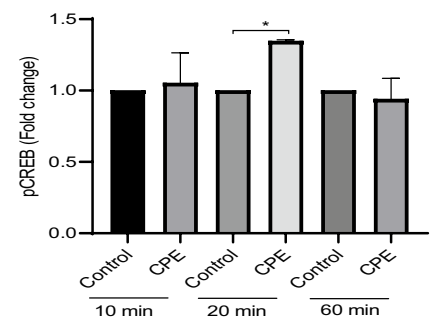

(d2)

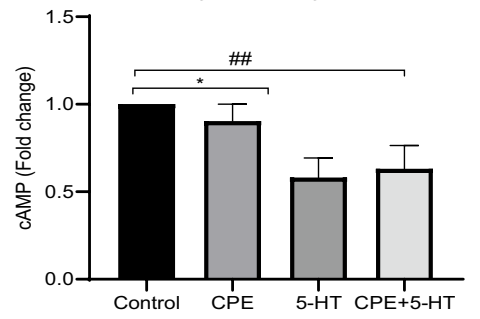

(f1)

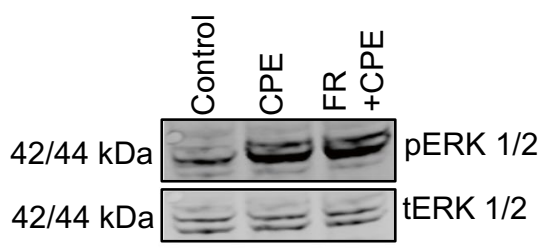

(f2)

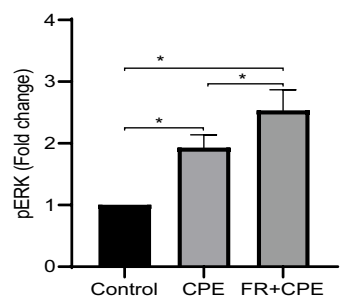

mean $\pm \mathrm{SD}, N=3$ (d). CPE does not affect forskolin-stimulated cAMP. 5-HTR1E stable cells (pretreated with $10 \mu \mathrm{M}$ forskolin for $10 \mathrm{~min}$ ) were treated with $50 \mathrm{nM}$ CPE, $1 \mu \mathrm{M}$ 5-HT, 5-HTR1E agonist BRL 54,443 (d1), or both $50 \mathrm{nM} \mathrm{CPE}$ and $1 \mu \mathrm{M}$ 5-HT (d2) simultaneously for $20 \mathrm{~min}$, and changes in cAMP levels were measured by cAMP-Glo $^{\text {TM }}$ Assay kit. One-way ANOVA analysis followed by Tukey's post hoc multiple comparison test, $[F(3,8)=24.7, p=0.0002]$, CPE $p=\mathrm{ns}, 5$-HT $* p=0.0109$, BRL $54,443 * p=0.0009$, CPE +5-HT ${ }^{*} p<0.0001$, compared to control, values are mean $\pm \mathrm{SD}, N=3$ (e-f). CPE-activated ERK phosphorylation is independent of $\mathrm{G}$ proteins. 5-HTR1E stable cells were treated with $200 \mathrm{ng}$ PTX (Gi inhibitor) for $4 \mathrm{~h}$ or $1 \mu \mathrm{m}$ FR900359 (Gq inhibitor) for $30 \mathrm{~min}$ followed by $50 \mathrm{nM}$ CPE (e1-2; f1-2) and pERK $1 / 2$ were analyzed by Western blotting. Bar graphs showing the fold change in pERK1/2 after normalization with tERK1/2 as an internal control. One-way ANOVA analysis followed by Tukey's post hoc multiple comparison test. For e1-2 $[F(2,6)=14.53, p=0.005]$, control vs CPE * $p=0.0097$, control vs CPE + PTX $* p=0.0070, N=3$. For f1-2 $[F(2,6)=33.90$, $p=0.0005]$, control vs CPE $* p=0.0062$, control vs CPE + FR900359 $* p=0.0004$, values are mean $\pm \mathrm{SD}, N=3$ 


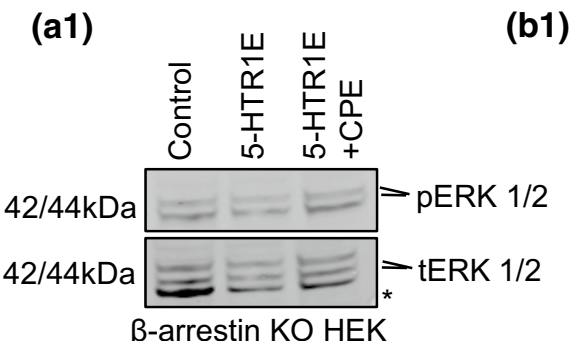

(a2)

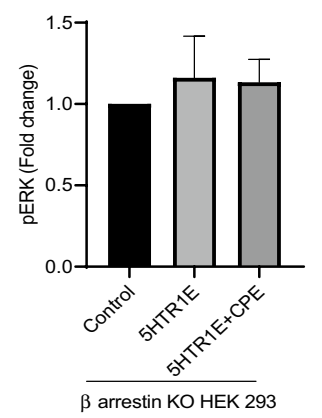

(e)

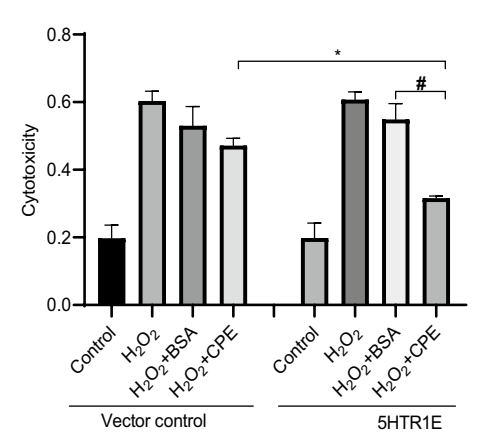

(b1)

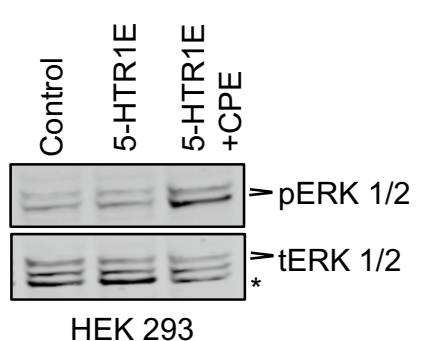

(b2)

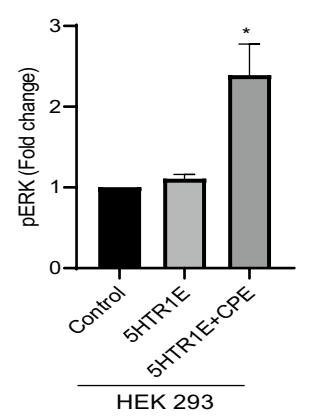

(f)

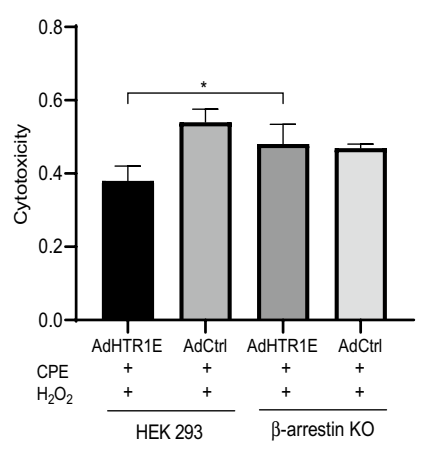

(c1)

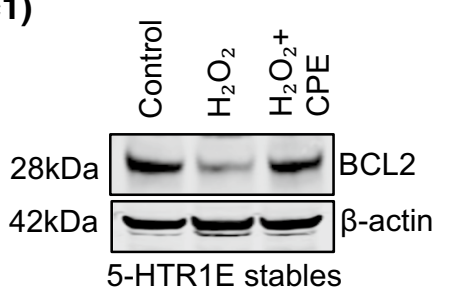

(c2)

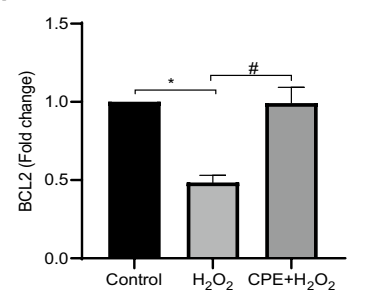

(d1)

(d2)

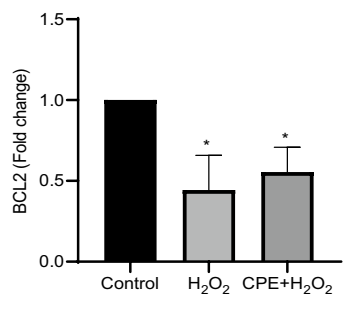

Fig. 4 a, b CPE-5-HTR1E-induced ERK is activated through $\beta$-arrestin. 5-HTR1E expressing $\beta$-arrestin KO HEK293 (a) and control (b) cells were treated with $50 \mathrm{nM} \mathrm{CPE}$ and pERK was analyzed by Western blotting. Bar graphs showing the fold change in pERK1/2 after normalization with tERK1/2 as an internal control. One-way ANOVA analysis followed by Tukey's post hoc multiple comparison test, a For $\beta$-arrestin KO HEK293 $[F(2,6)=0.7779, n s]$ and $\mathbf{b}$ for control HEK293 $[F(2,6)=35.33, p=0.0005]$, control vs 5 -HTR1E $p=n s$, control vs 5-HTR1E +5 -HT $* p=0.0007$, values are mean $\pm \mathrm{SD}, N=3$. (*) non-specific band (c-d). CPE protects against $\mathrm{H}_{2} \mathrm{O}_{2}$-induced oxidative stress via 5-HTR1E- $\beta$ arrestin. Western blot analysis of BCL2 protein in 5-HTR1E stable cells treated with $50 \mathrm{nM}$ CPE (c1-2) for $6 \mathrm{~h}$ followed by $200 \mu \mathrm{M} \mathrm{H}_{2} \mathrm{O}_{2}$ treatment overnight. Bar graphs showing quantification of BCL2 protein after normalization with $\beta$-actin. Results are expressed as fold change, One-way ANOVA analysis followed by Tukey's post hoc multiple comparison test, $[F(2,6)=63.70, p<0.0001]$, controls vs $\mathrm{H}_{2} \mathrm{O}_{2} * p=0.0002$, controls vs $\mathrm{H}_{2} \mathrm{O}_{2}+\mathrm{CPE} p=n s, \mathrm{H}_{2} \mathrm{O}_{2}$ vs $\mathrm{H}_{2} \mathrm{O}_{2}+\mathrm{CPE} \# p=0.0002$, values are mean $\pm \mathrm{SD}, N=3$, (d1-2) HEK293 cells devoid of 5-HTR1E

were performed in 5-HTR1E expressing, control and $\beta$-arrestin KO HEK293 cells. Figure 4f shows that treatment with NF- $\alpha 1 / \mathrm{CPE}$ did not protect 5-HTR1E expressing $\beta$-arrestin $\mathrm{KO}$ cells against $\mathrm{H}_{2} \mathrm{O}_{2}$-induced cytotoxicity, receptor were also analyzed for $\mathrm{BCL} 2,[F(2,6)=11.09, p=0.0096]$, controls vs $\mathrm{H}_{2} \mathrm{O}_{2} * p=0.0103$, controls vs $\mathrm{H}_{2} \mathrm{O}_{2}+\mathrm{CPE} p=0.0276$, $\mathrm{H}_{2} \mathrm{O}_{2}$ vs $\mathrm{H}_{2} \mathrm{O}_{2}+\mathrm{CPE} * p=0.6658$, value are mean $\pm \mathrm{SD}, N=3$. Lactate dehydrogenase (LDH) cytotoxicity assay (e) HEK 293 cells were transfected with 5-HTR1E or pCDNA 3.1 plasmid for $48 \mathrm{~h}$. Cells were treated with $50 \mathrm{nM}$ CPE or BSA followed by $300 \mu \mathrm{M} \mathrm{H}_{2} \mathrm{O}_{2}$ for $6 \mathrm{~h}$. One-way ANOVA analysis followed by Tukey's post hoc multiple comparison test $[F(7,16)=67.43, p<0.0001] \# p<0.0001$ for 5-HTR1E $+\mathrm{H}_{2} \mathrm{O}_{2}+\mathrm{CPE}$ compared to 5-HTR1E $+\mathrm{H}_{2} \mathrm{O}_{2}+\mathrm{BSA}$; ${ }^{*} p=0.0016$ for 5-HTR1E transfected cells $+\mathrm{H}_{2} \mathrm{O}_{2}+\mathrm{CPE}$ compared to vector control cells $+\mathrm{H}_{2} \mathrm{O}_{2}+\mathrm{CPE}$, values are mean $\pm \mathrm{SD}$, $N=3$. f Control and $\beta$-arrestin KO HEK293 cells were transduced with 5-HTR1E or control adenovirus for $48 \mathrm{~h}$. Cells were then treated with $50 \mathrm{nM}$ CPE followed by $300 \mu \mathrm{M} \mathrm{H} \mathrm{H}_{2} \mathrm{O}_{2}$ for $6 \mathrm{~h}$. Oneway ANOVA analysis followed by Tukey's post hoc multiple comparison test for LDH release assay: $[F(2,32)=27, p<0.0001]$ $* p<0.05$ for 5 -HTR1E $+\mathrm{H}_{2} \mathrm{O}_{2}+\mathrm{CPE}$ in HEK293 cells compared to 5-HTR1E $+\mathrm{H}_{2} \mathrm{O}_{2}+\mathrm{CPE}$ in $\beta$-arrestin $\mathrm{KO}$ HEK293 cells, values are mean $\pm \mathrm{SD}, N=3$

unlike 5-HTR1E-expressing HEK293 cells. Thus, the function of the NF- $\alpha 1 / \mathrm{CPE}-5-\mathrm{HTR} 1 \mathrm{E}$ interacting complex in promoting cell survival during $\mathrm{H}_{2} \mathrm{O}_{2}$-induced oxidative stress requires recruitment of $\beta$-arrestin. 
Fig. 5 High-affinity CPE-5HTR1E- $\beta$-arrestin 1 complex. a The side view of the fully active CPE-5-HTR1E- $\beta$-arrestin1 complex derived from $\sim 1.5 \mu \mathrm{s}$ MD simulations colored by subunits: CPE (pink), 5-HTR1E (green), and $\beta$-arrestin1 (purple). b Tight coupling between the phosphorylated ICL3 of 5-HTR1E and the N-domain of $\beta$-arrestin 1 , mostly involving the salt bridges from $\mathrm{pS}$ and $\mathrm{pT}$ to positively charged residues on the $\mathrm{N}$-domain of $\beta$-arrestin1. c Analysis of the active-state conformation of 5-HTR1E upon recruiting $\beta$-arrestin1. d Ionic anchors from $\beta$-arrestin 1 to the ICL1 and ICL2 of 5-HTR1E. e Analysis of the conformation of the $\beta$-arrestin1 upon engaging the 7TM core of 5-HTR1E in the presence of CPE. To evaluate the inter-domain twist, we superimposed the $\mathrm{N}$-domain of the active (obtained from our MD simulation) to the inactive (resolved by experiment, PDB ID: 1G4M) state of the $\beta$-arrestin1. f Distribution of the inter-domain twist angle once the of $\beta$-arrestin1 binds the 5-HTR1E (a)

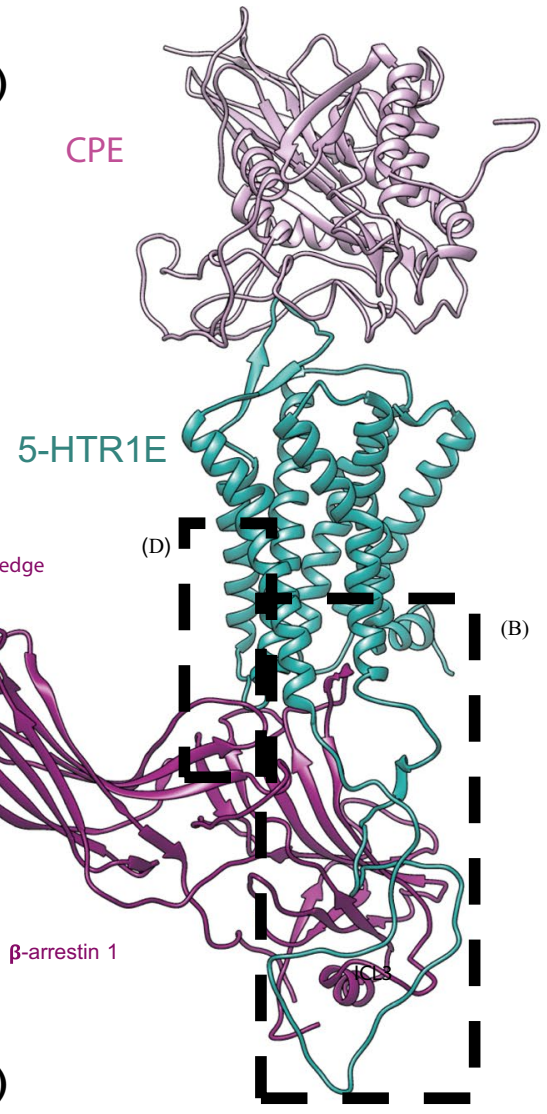

(c)

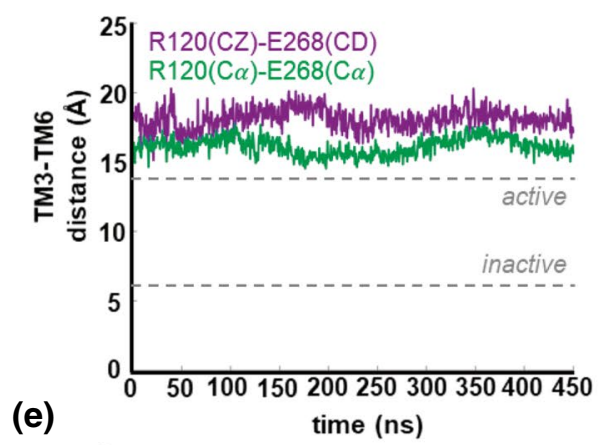

(e)

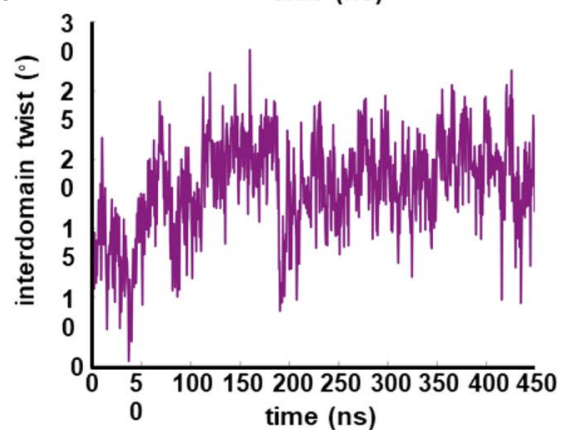

(b)

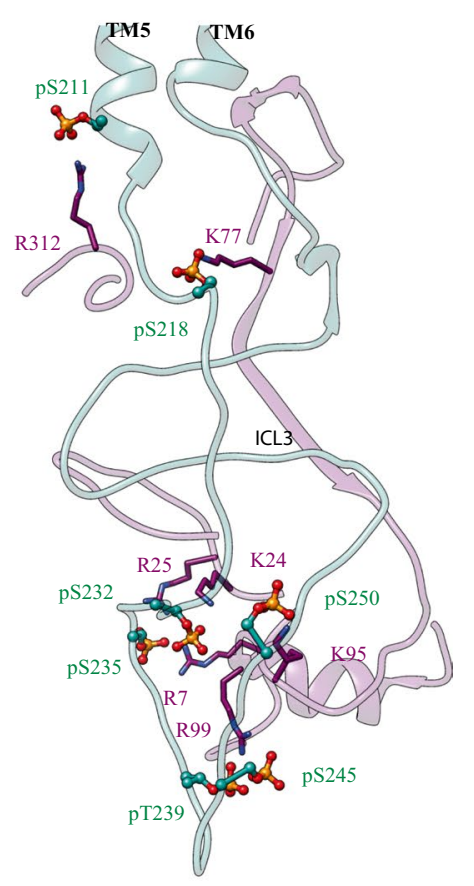

(d)

(f)
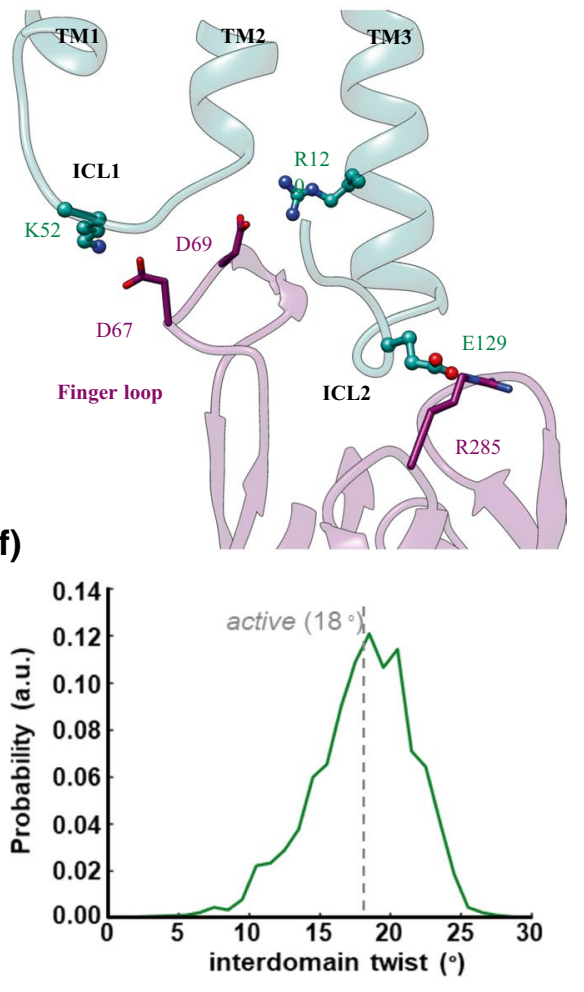

\section{Molecular dynamics studies predict the NF-a1/CPE- 5-HTR1E complex activates $\beta$-arrestin}

To investigate the cellular signaling mechanism regulated through arrestin pathways, we carried out molecular dynamics studies to predict the interactions of the highaffinity NF- $\alpha 1 /$ CPE-5-HTR1E complex with $\beta$-arrestin 1 . An overview of our optimized protein construct is shown in Fig. 5a and suppl. Fig. SK5. Previous studies showed that phosphorylation of intracellular loop (ICL) 3 in GPCRs, 
plays a crucial role in the recruitment and activation of $\beta$-arrestins [35-37].

In order to predict the interaction of $\beta$-arrestin 1 with the NF- $\alpha 1 / C P E-5-H T R 1 E$ complex, we started with the cryoEM M2 muscarinic receptor- $\beta$-arrestin 1 complex (PDB ID: 6U1N) [38] as a template and superimposed 5-HTR1E on the M2 muscarinic receptor to insert the $\beta$-arrestin 1 into the cytoplasmic region of NF- $\alpha 1 / \mathrm{CPE}-5$-HTR1E complex after phosphorylating the Ser and $\mathrm{Thr}$ in the $\mathrm{C}$-terminus and ICL3. Subsequently, we immersed the predicted NF- $\alpha 1 /$ CPE-5-HTR1E- $\beta$-arrestin 1 complex into a lipid bilayer composed of 290 palmitoyl-2-oleoyl-sn-glycero-3-phosphocholine (POPC) molecules. Then we solvated this system with water and ions (sodium chloride) to neutralize the system at the physiological concentration of $0.15 \mathrm{M}$. This leads to $\sim 185,000$ atoms in a simulation box of $100 \times 100 \times 172$ $\AA^{3}$. We assigned the protonation state of protein residues at the physiological $\mathrm{pH}=7.4$. We carried out an aggregate of $\sim 1.4 \mu$ s molecular dynamics simulations to optimize our protein construct. We then used the results of the last $450 \mathrm{~ns}$ frames for the analysis presented in this study.

Although the long C-tail and ICL3 are primary sites of phosphorylation in GPCRs [35-37], the long C-tail of 5-HTR1E does not feature any serine or threonine residues to be phosphorylated, leaving the ICL3 with 14 serine and 6 threonine as candidate phosphorylation sites for $\beta$-arrestin recruitment. However, the phosphorylation state of these 20 residues is not available from experiment (neither from this study nor from previous works). Thus, in our MD studies, we considered full phosphorylation at all serine $(\mathrm{pS})$ and threonine (pT) residues on the ICL3. This follows the same procedure [39] that we used successfully to study the recruitment of $\beta$-arrestin 2 by m-opioid receptor. Our MD studies reported here show that the fully phosphorylated ICL3 interacts strongly with the $\mathrm{N}$-domain of $\beta$-arrestin 1 , leading to the emergence of numerous salt bridge interactions (Fig. 5b): pS211-R312, pS218-K77, pS235-R25, pS235-R7, pT239-R99, pS245-R99, and pS250-K95, which play a pivotal role in stabilizing the fully activated state of $\beta$-arrestin 1 in the NF- $\alpha 1 /$ CPE-5-HTR1E- $\beta$-arrestin 1 complex (Fig. 5a).

Thus, the fully active NF- $\alpha 1 / \mathrm{CPE}-5$-HTR1E complex facilitates $\beta$-arrestin recruitment. We find that the finger loop of $\beta$-arrestin 1 penetrates deep into the core of 5-HTR1E to establish a persistent salt bridge from D69 to R120 3.50 (Fig. 5d). This salt bridge interaction prevents ionic lock formation between R120 $0^{3.50}(\mathrm{CZ})$-E268 $8^{6.30}(\mathrm{CD})$, allowing 5-HTR1E to adopt a fully open cytoplasmic region.

We find that the C-edge loops, ${ }^{189}{ }^{\text {QFLMSDKP }}{ }^{196}$, ${ }^{223}{ }^{N T N K T V K K I}{ }^{231}$, and ${ }^{329}$ VSRGGLLGDLASS ${ }^{341}$ of the $\beta$-arrestin 1 anchor extensively to the lipid bilayer, allowing $\beta$-arrestin1 to maintain its active conformation with an averaged inter-domain twist angle of $\sim 18.8^{\circ}$ (Fig. 5e-f). The lipid anchors serve a pivotal role in stabilizing the high-affinity arrestin-GPCR complex since we find that elimination of this lipid-anchoring transits causes the fully active conformation from relax- to inactive-state conformation [38, 39]. Interestingly, our MD simulation indicates that the activated $\beta$-arrestin 1 couples the phosphorylated 5-HTR1E by forming ionic anchors to ICL1: D67-K52 $2^{\text {ICL1 }}$ and ICL2: R285-E129 ${ }^{\text {ICL2 }}$ (Fig. 5d), which sterically discourage Gi protein from coupling to the same binding site in the 5-HTR1E.

\section{5-HTR1E and NF-a1/CPE are co-localized in human hippocampal neurons}

To determine if 5-HTR1E co-expresses with NF- $\alpha 1 / \mathrm{CPE}$ in the human brain, we carried out immuno-histochemical and immunofluorescence studies on post-mortem human brains (Suppl. Table S5, Fig. 6a, b, Fig. S5-S9). These and Western blot studies (Fig. 7a) revealed that 5-HTR1E and NF- $\alpha 1 / C P E[40]$ were present in the human hippocampus (Fig. 6ai-iii). Low-magnification images show co-expression of both 5-HTR1E and NF- $\alpha 1 / \mathrm{CPE}$ in neurons in the pyramidal cell layer in Cornu Ammonis areas CA1, CA2 and CA3 and within de Hilus in dentate gyrus (DG) (Fig. 6aiv-vii and Suppl. Fig. S5, S6, S9 using 2 different 5-HTR1E antibodies). Images at higher magnification show 5-HTR1E is located mainly within the perikarya of pyramidal cells and within the granule cell layer of DG. NF- $\alpha 1 / \mathrm{CPE}$ is found in the perikarya of pyramidal cells, the apex, and terminal dendrites along the stratum radiatum $(\mathrm{Sr})$ in $\mathrm{CA}$ areas (Fig. 6a viii-x). High-magnification images represented in Fig. $6 \mathrm{~b}$ were used to quantify the co-expression frequency of NF- $\alpha 1 /$ CPE. Up to $90 \%$ of cells expressing 5 -HTR1E co-expressed with NF- $\alpha 1 / \mathrm{CPE}$ in the different sub-regions of the hippocampus. No statistical differences were found when comparing both $\%$ of cells co-expressing 5-HTR1E and NF- $\alpha 1 / \mathrm{CPE}$ and $\%$ of cells expressing only 5 -HTR $1 \mathrm{E}$ in any of the different hippocampal sub-regions (Fig. 6a xi). Analysis of 5-HTR1E and NF- $\alpha 1 / \mathrm{CPE}$ labeling at the cell membrane suggests that they co-localize and could potentially interact within human hippocampal CA3 neurons (Fig. 6b i-ii), as well as within CA1, CA2 and DG neurons (Suppl. videos 1-4). Z-stack reconstructions and quantitative co-localization analysis were performed to confirm and determine the levels of co-localization between 5-HTR1E and NF- $\alpha 1 / \mathrm{CPE}$ in hippocampal neurons. The analyses showed cell membrane co-localization of 5-HTR1E and NF- $\alpha 1 / \mathrm{CPE}$ at similar levels in the different hippocampal subfields except for CA2 where co-localization levels were lower (Fig. 6b iii). These results suggest possible functional interaction between NF- $\alpha 1 / \mathrm{CPE}$ and 5 -HTR1E in human neurons in vivo. 
(a)
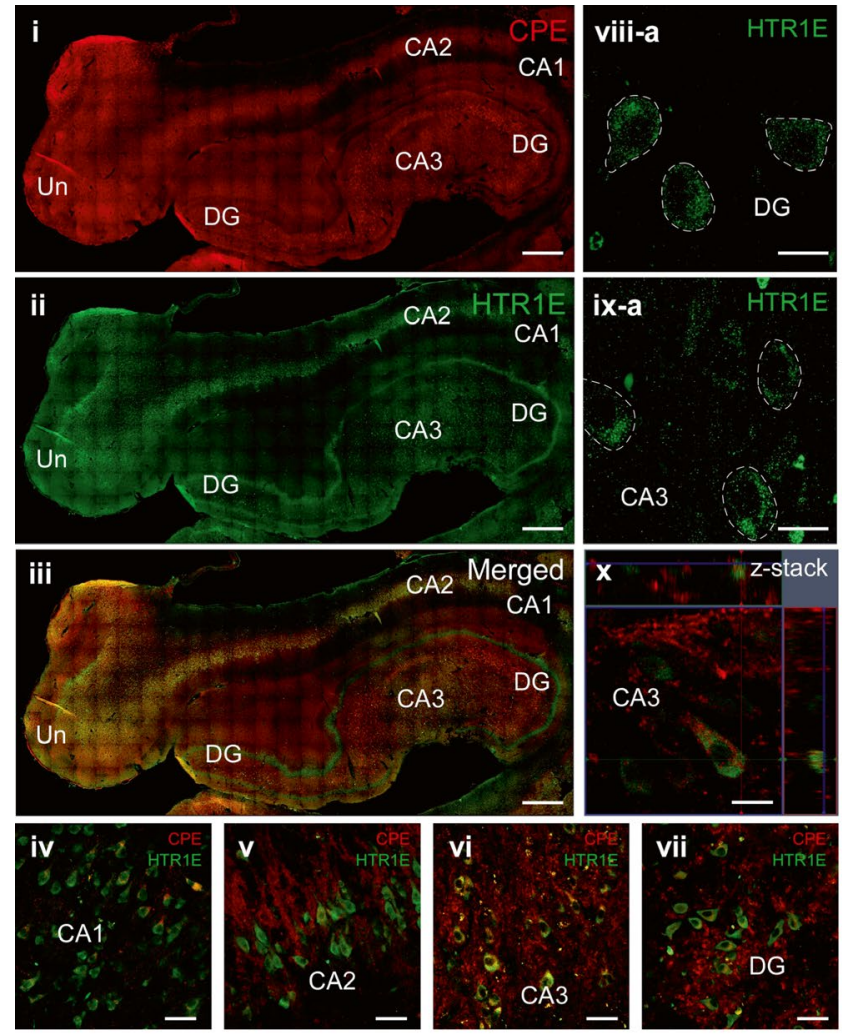

(b) (i)

(ii)
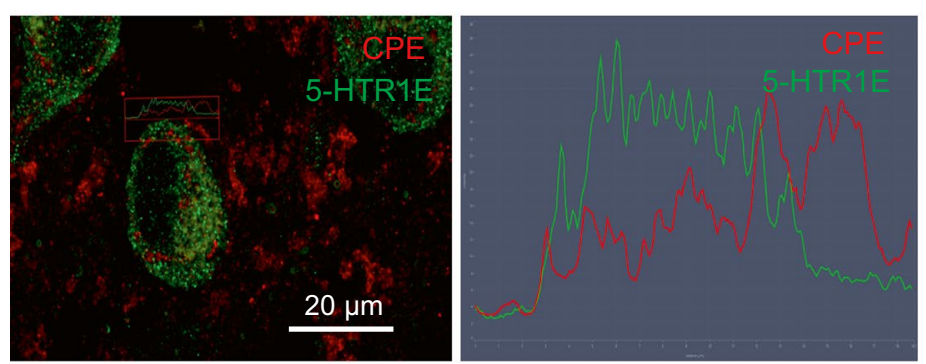
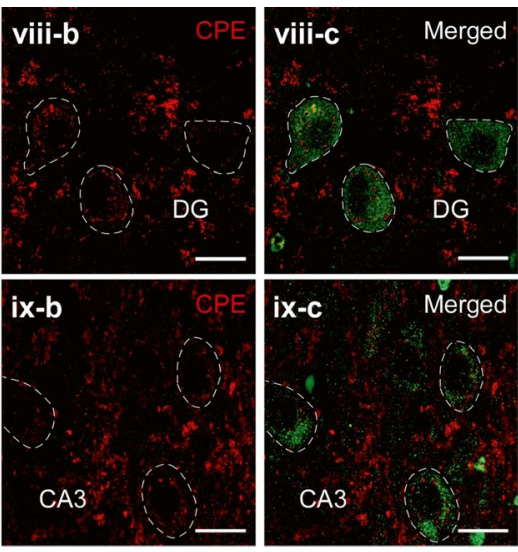

(xi)

HTR1E and CPE expression

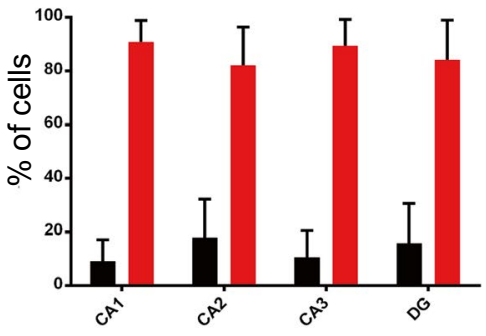

- Cells with HTR1E labeling

Cells with HTR1E + CPE labeling

(iii)

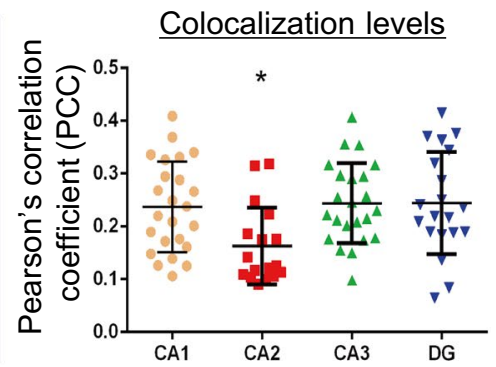

Fig. 6 a Distribution and cellular co-expression of CPE and 5-HTR1E in human hippocampus. Mosaic of confocal microscope images at $10 \times$ of human hippocampus (Bregma $17.2 \mathrm{~mm}$ ) showing distribution of CPE (i), 5-HTR1E (ii) and merged (iii). Example of $\mathrm{CPE}$ and 5-HTR1E co-expression in neurons in CA1 (iv), CA2 (v), CA3 (vi) and within the hilus in DG (vii). High-magnification images showing co-expression of 5-HTR1E and CPE in CA3 pyramidal neurons (viii-a-c) and DG neurons (ix-a-c). Z-stack of CA3 pyramidal neurons (x) illustrates the distributions and co-expression of CPE and 5-HTR1E along the thickness of the $z$-axis. (xi)The co-expression of CPE and 5-HTR1E was observed in four different human hippocampus and in rostral and caudal sections as well. A total of 190 cells taken from high magnification images as illustrated in $\mathbf{b}$ were quantified. Bar graphs show the \% of cells expressing 5-HTR1E and cells co-expressing 5-HTR1E and NF- $\alpha 1 / \mathrm{CPE}$ in the different hippocampal sub-regions. The \%s within the different hippocampal sub-regions are very similar. No significant differences were observed either in
5-HTR1E-expressing cells or in 5-HTR1E- and NF- $\alpha 1 /$ CPE-coexpressing cells between the CA1, CA2, CA3 and DG $(p=0.4647$; one-way ANOVA test). Scale bar: i-iii $=1000 \mu \mathrm{m}$, iv-v $=50 \mu \mathrm{m}$, vivii $=100 \mu \mathrm{m}$ and viii- $\mathrm{x}=20 \mu \mathrm{m}$. b Co-localization levels of CPE and 5-HTR1E on cell membrane. (i, ii): Image of the part of cell where profile was performed (left). Graph showing the intensity of labeling of both markers across the distance of the profile (right). Scale bar $=20 \mu \mathrm{m}$. (iii): Pearson's correlation coefficient (PCC) of 84 regions of interest (ROI) [CA1 (24 cells), CA2 (17 cells), CA3 (23 cells) and DG (20 cells)] were quantified. Levels of co-localization of the 5-HTR1E and NF- $\alpha 1 / \mathrm{CPE}$ on the cell surface membrane are presented from 0 (no correlation) to 1 (perfect correlation). CA2 shows lower levels of co-localization in contrast to CA1, CA3 and DG subregions ( ${ }^{*} p=0.0102$; one-way ANOVA test). The level of co-localization is consistent with ligand interaction with receptors being a dynamic phenomenon 
(a)

hippocampus

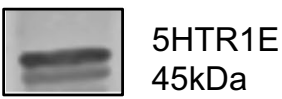

(c1)

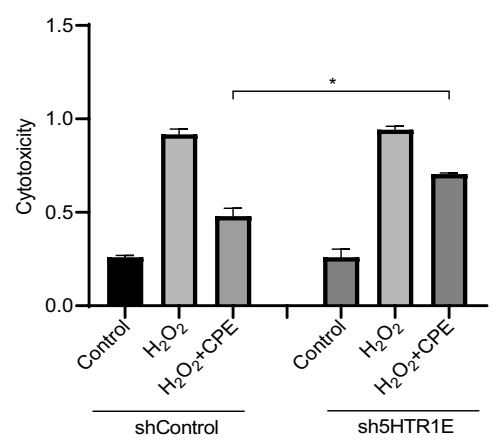

(c2)

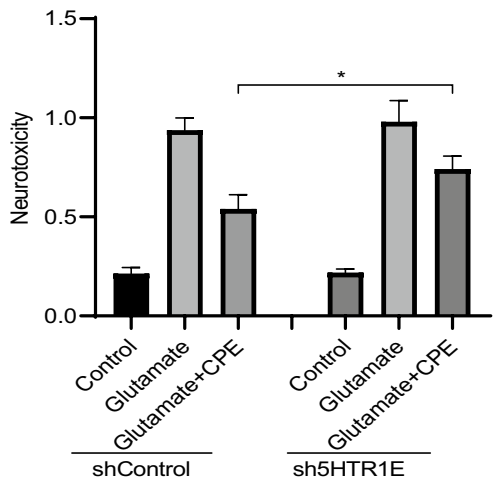

Fig. 7 a 5-HTR1E expression in human hippocampus. b 5 -HTR1E-NF- $\alpha 1 / \mathrm{CPE}$ interaction protects human neurons against $\mathrm{H}_{2} \mathrm{O}_{2}$-induced oxidative stress. b1 Western blot and b2 image $\mathbf{J}$ quantification showing $48 \% \mathrm{KO}$ of 5 -HTR1E in human neurons treated with AV-5-HTR1E shRNA compared to control AV for $72 \mathrm{~h}$. [F (2, $3)=170.0, p=0.0008],{ }^{*} p=0.0008$ for Control vs sh-5-HTR1E, $p=0.3266$ for Control vs shControl, values are mean $\pm \mathrm{SD}, n=2$. c1, c2 Bar graphs show decreased neuroprotective effect of NF- $\alpha 1 /$ CPE in 5-HTR1E-KO vs control neurons, against $\mathrm{H}_{2} \mathrm{O}_{2}$ - or gluta-

\section{Down-regulation of 5-HTR1E expression inhibits neuronal cell survival}

To determine if 5-HTR1E interaction with NF- $\alpha 1 / \mathrm{CPE}$ could mediate neuroprotection of human primary neurons, we down-regulated 5-HTR1E expression and challenged these

(d) (b2)

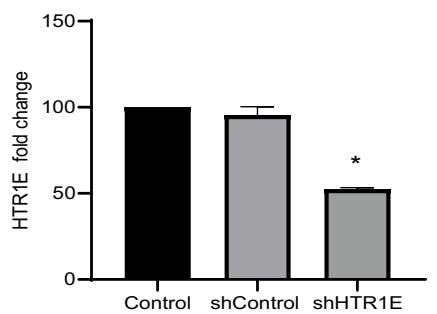

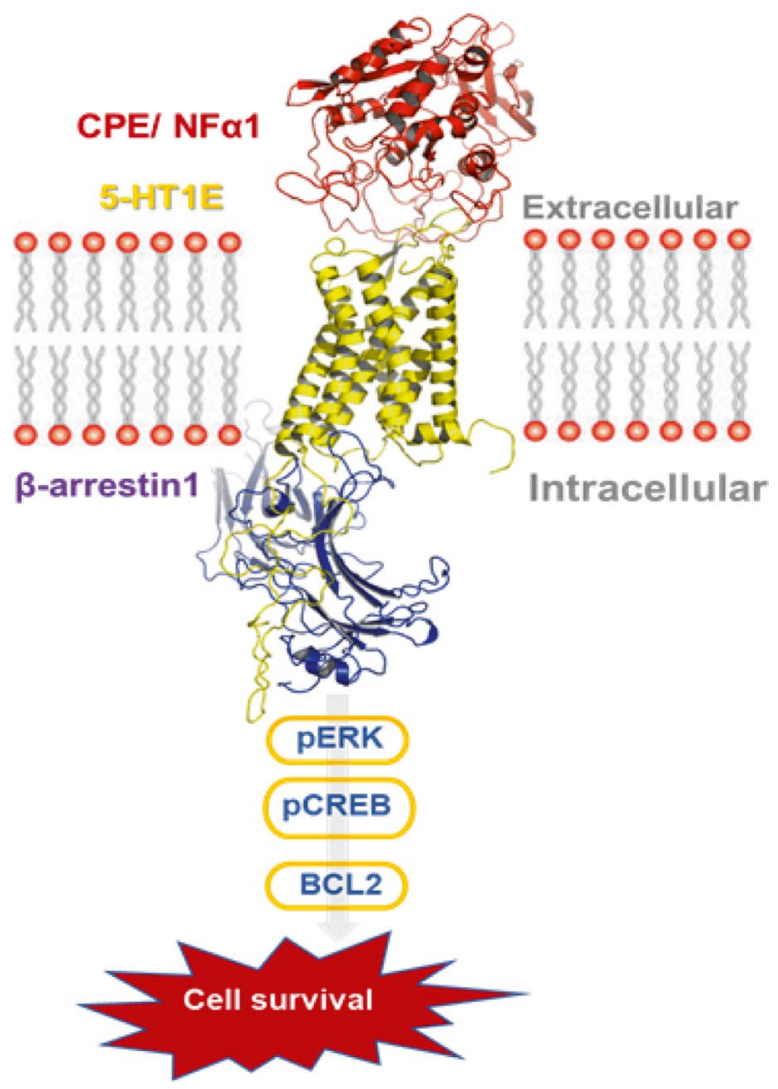

mate-induced cytotoxicity assessed by LDH assay. One-way ANOVA analysis followed by Tukey's post hoc multiple comparison test. For $\mathrm{H}_{2} \mathrm{O}_{2}$ experiments (c1) $[F(6,14)=533.0, p<0.0001] * p<0.0001$ for $\mathrm{CPE}+\mathrm{H}_{2} \mathrm{O}_{2}$ in control neurons compared to $\mathrm{CPE}+\mathrm{H}_{2} \mathrm{O}_{2}$ in 5-HTR1E-KO neurons. For glutamate experiments $($ c2) $[F(6$, 14) $=118.2, p<0.0001] * p=0.0170$ for CPE + glutamate in control neurons compared to $\mathrm{CPE}+$ glutamate in 5-HTR1E- KO neurons. Values are mean $\pm \mathrm{SD}, N=3$. d Model of Proposed NF- $\alpha 1 / \mathrm{CPE}-5$ HTR1E signaling mechanism

neurons with $\mathrm{H}_{2} \mathrm{O}_{2}$ or glutamate to induce oxidative or neurotoxic stress, respectively, in the presence of NF- $\alpha 1 / \mathrm{CPE}$. Treatment of neurons with adenovirus-5HTR1E-shRNA reduced 5-HTR1E expression by $\sim 50 \%$ (Fig. 7b1, b2). Figure $7 \mathrm{c} 1$ and $\mathrm{c} 2$ shows that pre-treatment with NF- $\alpha 1 /$ CPE effectively reduced $\mathrm{H}_{2} \mathrm{O}_{2}$ or glutamate-induced cyto/ 
neurotoxicity in cultured human primary neurons. However, when these neurons were down-regulated in expression of 5 -HTR1E, the effect of pretreatment with NF- $\alpha 1 / \mathrm{CPE}$ on the reduction of cyto/neurotoxicity when challenged with $\mathrm{H}_{2} \mathrm{O}_{2}$ or glutamate was significantly less compared to control neurons. Thus, 5-HTR1E plays a pivotal role in protecting human neurons against oxidative and neurotoxic stressinduced cell death, through interaction with NF- $\alpha 1 / \mathrm{CPE}$.

\section{Discussion}

\section{Serotonin receptor 5-HTR1E interaction with NF-a1/ CPE promotes cell survival}

Identifying molecular systems that can protect neurons against various type of stress is important to prevent cognitive dysfunction and neurodegenerative diseases. In this study, we have discovered that the interaction between a new trophin, NF- $\alpha 1 / \mathrm{CPE}$, and the 5-HTR1E GPCR, a member of the serotonin receptor family with previously unknown function in the brain, produces a strong effect on promoting neuronal survival during oxidative and neurotoxic stress. Interestingly, this cell protective system seems to have evolved for humans and primates since the HTR $1 E$ gene is not found in mice or rats $[19,41]$. Using HEK293 human cells as a model system, we showed that NF- $\alpha 1 / \mathrm{CPE}$ can prevent $\mathrm{H}_{2} \mathrm{O}_{2}$-induced cytotoxicity in 5-HTR1E-transfected HEK293 cells, but not in mock-transfected HEK293 cells.

Most importantly, we showed that 5-HTR1E-NF- $\alpha 1 /$ CPE interaction protected human primary neurons from cell death when challenged with $\mathrm{H}_{2} \mathrm{O}_{2}$ or glutamate, which induced oxidative or neurotoxic stress, respectively. Knockdown of 5-HTR1E reduced this neuroprotective activity in neurons subjected to oxidative/neurotoxic stress. These findings demonstrate an important role of 5-HTR1E as a receptor for $\mathrm{NF}-\alpha 1 / \mathrm{CPE}$ in mediating neuroprotection in human neurons. Since it is known that NF- $\alpha 1 / \mathrm{CPE}$ is highly expressed in stress-vulnerable hippocampal CA3 neurons, in the human brain [40], and is critical in the prevention of stress-induced hippocampal neuronal cell death in mice [4], we carried out immuno-histochemical studies on postmortem human brains to determine if there is co-expression and co-localization of 5-HTR $1 \mathrm{E}$ and NF- $\alpha 1 / \mathrm{CPE}$ in hippocampal neurons that could indicate the possibility of functional interaction of these molecules in vivo. Immunofluorescence studies revealed that 5 -HTR1E and NF- $\alpha 1 / \mathrm{CPE}$ are co-expressed in the same pyramidal neurons in the CA1, $\mathrm{CA} 2$, and CA3 region, and in the dentate gyrus (DG) neurons. This is a broader distribution of 5-HTR1E than in the guinea pig hippocampus where expression was only reported in the DG [22]. Z-stack reconstructions indicate co-localization of NF- $\alpha 1 / \mathrm{CPE}$ and 5-HTR1E at the cell membrane of hippocampal neurons. These data strongly suggest that NF- $\alpha 1 /$ CPE after secretion from the neuron, could bind to 5-HTR1E to mediate neuroprotection and cell survival in the human hippocampus, in an autocrine/paracrine manner.

\section{NF-a1/CPE interacts with 5-HTR1E to activate $\beta$-arrestin/ERK/BCL2 pathway}

To elucidate the mechanism of action of 5-HTR1E, we first demonstrated using luciferase reporter assay [24] that NF- $\alpha 1 / \mathrm{CPE}$ was able to activate 5-HTR1E in HTLA cells after treatment with recombinant NF- $\alpha 1 / \mathrm{CPE}$ extracellularly. Our radioligand-binding experiments showed that NF- $\alpha 1 / \mathrm{CPE}$ binds to 5-HTR1E specifically and in a saturable manner with high affinity, $(\mathrm{Kd}=13.82 \mathrm{nM})$ when 5-HTR1E-expressing HEK293 stable cells were treated with $\left[{ }^{125} \mathrm{I}\right] \mathrm{NF}-\alpha 1 / \mathrm{CPE}$. The binding affinity of NF- $\alpha 1 / \mathrm{CPE}$ to 5-HTR1E was lower than some, and similar to other glycoprotein hormones binding to their respective GPCRs [42-44]. Interaction between NF- $\alpha 1 / \mathrm{CPE}$ and 5-HTR1E was further confirmed in LN-18 cells, a human glioblastoma cell line that expresses both the ligand and receptor endogenously. Co-immunoprecipitation assays showed that NF- $\alpha 1 / \mathrm{CPE}$ antibodies pulled down 5-HTR1E, indicating interaction between these two molecules. Furthermore, our pull-down experiments showed that full-length NF- $\alpha 1 /$ CPE and a CPE fragment comprising residues $1-350$, but not fragments $1-150$ or 351-476 interacted with 5-HTR1E. This finding indicated that the binding domain of NF- $\alpha 1 /$ CPE to 5-HTR1E is likely within residues $151-350$ which corroborated with our molecular dynamics studies. It is of note that there is always a possibility that improper folding could affect results of pull-down assays. Hence, future testing of the binding activities between CPE and 5-HTR1E after mutating specific amino acid residues on CPE predicted to interact with 5-HTR1E by molecular docking and dynamics studies, will be carried out to further confirm our model experimentally.

Our studies showed that NF- $\alpha 1 / \mathrm{CPE}-5$-HTR1E activated a signal transduction mechanism leading to cell survival which involved ERK phosphorylation. Upon NF- $\alpha 1 /$ CPE binding to 5-HTR1E stable cells, there was a 3.4-fold increase in pERK1/2 compared to normal HEK293 cells. It has been reported that ERK phosphorylation leads to activation of its downstream protein CREB, which then regulate the level of the pro-survival protein BCL2 to protect cells against oxidative stress $[45,46]$. Our studies found that NF- $\alpha 1 / \mathrm{CPE}$ increased phosphorylation of CREB up to $30 \%$ in 5-HTR1E-expressing cells compared to controls. Furthermore, after treatment with $\mathrm{H}_{2} \mathrm{O}_{2}$, to induce oxidative stress, the decrease in BCL2 protein level was prevented in NF- $\alpha 1 /$ CPE-treated 5-HTR1E stable cells as compared to normal HEK293 cells. Thus, NF- $\alpha 1 /$ CPE-5-HTR1E interaction 
promotes cell survival via activation of the ERK/CREB/ BCL2 pathway.

GPCRs can stimulate ERK phosphorylation through different pathways, such as through G proteins [47] or through recruitment of arrestin which can function as an independent mediator of G proteins [48]. Since 5-HTR1E is a Gi-linked receptor [17], we tested the Gi inhibitor, PTX, and a Gq inhibitor FR900359 [34], and found that neither inhibitor had an effect on inhibiting NF- $\alpha 1 / C P E$ activation of ERK expression in 5-HTR1E stable cells. However, we were able to show that the NF- $\alpha 1 /$ CPE-induced ERK $1 / 2$ phosphorylation in 5-HTR1E stable cells was diminished in HEK293- $\beta$ arrestin-KO cells. This finding indicates that $\beta$-arrestin is critical in HTR1E-mediated ERK phosphorylation. Furthermore, upon treatment with NF- $\alpha 1 / \mathrm{CPE}, 5$-HTR1E-expressing $\beta$-arrestin KO HEK293 cells were unable to mitigate the $\mathrm{H}_{2} \mathrm{O}_{2}$-induced cytotoxicity compared to control 5-HTR1Eexpressing HEK293 cells. Thus, arrestin recruitment by the NF- $\alpha 1 / C P E-5-H T R 1 E$ complex is pivotal in activating the ERK/CREB/BCL2 pathway.

It is known that 5-HTR1E, upon binding with 5HT inhibits the cAMP pathway $[17,49]$. However, when we treated 5 -HTR1E stable cells with NF- $\alpha 1 / \mathrm{CPE}, 5-\mathrm{HT}$ or BRL54443 (5-HTR1E agonist) in the presence of forskolin, we found no effect of NF- $\alpha 1 / \mathrm{CPE}$ on forskolin-stimulated cAMP, while 5-HT or BRL54443 both reduced cAMP levels significantly. This result shows that the NF- $\alpha 1 / \mathrm{CPE}-5$-HTR1E complex does not activate cAMP signaling which is limited to 5-HTR1E stimulation by serotonin. While serotonin was able to induce ERK signaling in 5-HTR1E stable cells, it did not up-regulate BCL2 protein expression (Fig. S4), suggesting that the neuroprotection effect resulting from interaction of NF- $\alpha 1 / \mathrm{CPE}$ with 5 -HTR1E is independent of serotonin interaction with this receptor.

\section{Structural mechanism for NF-a1/CPE and 5-HTR1E interaction and recruitment of $\beta$-arrestin, independent of serotonin pocket}

Molecular dynamics (MD) studies were carried out to understand the interactions at the molecular level between NF- $\alpha 1 / \mathrm{CPE}$ and 5-HTR1E, and subsequent recruitment of $\beta$-arrestin. First, we generated an active structure for 5-HTR1E and predicted that the binding of CPE to 5-HTR1E, is not at the serotonin-binding pocket. Instead, we found that NF- $\alpha 1 / \mathrm{CPE}$ interacts with the ECL1/ECL2 of 5-HTR1E via 3 stable salt bridges composed of K302D86 ${ }^{\mathrm{ECL} 1}, \mathrm{D} 306-\mathrm{K} 89^{\mathrm{ECL} 1}, \mathrm{D} 275-\mathrm{R} 165^{\mathrm{ECL} 2}$. Then using MD techniques to phosphorylate the Ser and Thr in ICL3 of 5-HTR1E and allowing it to interact with $\beta$-arrestin1, we found very strong coupling of $\beta$-arrestin1 to ICL2 and ICL3 of 5-HTR1E, leading to activation of $\beta$-arrestin1. This demonstrates how the binding of NF- $\alpha 1 / \mathrm{CPE}$ to 5-HTR1E can induce $\beta$-arrestin1 activation, which we conclude is responsible for the cell survival effect provided by NF- $\alpha 1 / \mathrm{CPE}$ interacting with 5-HTR1E.

\section{Conclusion}

We have discovered a new role for 5-HTR1E serotonin receptor, which previously had no neurophysiological function. The novel interaction of 5-HTR1E with NF- $\alpha 1 / \mathrm{CPE}$ uncovered a new mechanism for promoting neuroprotection of human neurons during induced oxidative and neuroexcitotoxic stress (Fig. 7d). Cell biological and molecular dynamics studies indicate that the mechanism of signaling for 5-HTR1E to promote cell survival involves activation of the ERK-CREB-BCL2 signaling pathway, via recruitment of $\beta$-arrestin, which is infrequent among GPCRs. Since the 5-HTRIE gene is expressed in humans and primates, but not rats or mice, this cell survival/protective mechanism may be of specific importance to Homo sapiens, especially in the human hippocampus where both molecules are poised for interaction since they are co-localized in neuronal surface membranes. Interestingly, since our previous work on mice and rats suggests a similar receptor-mediated mechanism in the transduction of neuroprotective activity of NF- $\alpha 1$ / CPE $[4,13]$, other receptors must be involved and yet to be identified in these species. Our discovery and molecular understanding of how 5-HTR1E interacts with NF- $\alpha 1 /$ $\mathrm{CPE}$ to promote neuronal survival pave the way for design of small molecule agonists to the 5-HTR1E for potential therapeutic use in preventing and treatment of human neurodegenerative diseases.

Supplementary Information The online version contains supplementary material available at https://doi.org/10.1007/s00018-021-04021-3.

Acknowledgements Authors are indebted to the IDIBAPS, BTCIEN, and BIOBANC-MUR Biobanks for the human sample and data procurement. We thank Dr. Xi-Ping Huang in Dr. Bryan Roth's lab (UNC) who did the first GPCR screen. We also thank Dr. Jurgen Wess (NIDDK), for very helpful suggestions regarding the GPCR experiments; Prof. Evi Kostenis and Prof. Gabriele M. König, Molecular, Cellular and Pharmacobiology Section, Institute of Pharmaceutical Biology, University of Bonn, 53115 Bonn, Germany, for providing the Gq inhibitor FR900359 and Drs. David Sibley (NINDS), Lee Eiden (NIMH), Sangeetha Hareendran (NICHD) and Hong Lou (NICHD) for helpful discussions.

Author contributions YPL designed the research project; VKS, XY, DSS, LX, LT, and PVA performed the experimental research. S-KK, $\mathrm{AM}$, and WAG performed the MD and modeling studies and analyzed the results. YPL, VKS, XY, DSS, LX analyzed the experimental data; YPL and VKS wrote the paper with contributions of various sections from XY, LX, DSS, S-KK, AM and WAG.

Funding This research was in part supported by the Intramural Research Program of the Eunice Kennedy Shriver National Institute of Child Health and Human Development (NICHD), National Institutes 
of Health, USA. The work was also sponsored by the Spanish Ministry of Economy and Competitiveness-FEDER (grant \#SAF201675768-R) and the Autonomous Government of Castilla-La Mancha/ FEDER (grant no. SBPLY/17/180501/000430). The Caltech team received support from the Margaret Early Medical Research Trust and from NIH (R35HL150807). Additional funding was provided by gifts to the MSC at Caltech. Dr. Asuka Inoue's work was funded by the PRIME JP19gm5910013 and the LEAP JP19gm0010004 from the Japan Agency for Medical Research and Development (AMED).

Availability of data and material The data sets generated during and/or analyzed during the current study are available from the corresponding author on reasonable request.

\section{Declarations}

Conflict of interest The authors declare no conflict of interest.

Ethics approval and consent to participate Permission to use commercially available human brain neurons was obtained from NIH (Project no. 000501). For human postmortem brain tissues, all the experimental procedures were approved by the Ethical Committee of Clinical Research at Ciudad Real University Hospital (grant numbers SAF201675768-R and SBPLY/17/180501/000430).

Consent for publication All the authors listed in the article give their consent for the publication of this article.

Open Access This article is licensed under a Creative Commons Attribution 4.0 International License, which permits use, sharing, adaptation, distribution and reproduction in any medium or format, as long as you give appropriate credit to the original author(s) and the source, provide a link to the Creative Commons licence, and indicate if changes were made. The images or other third party material in this article are included in the article's Creative Commons licence, unless indicated otherwise in a credit line to the material. If material is not included in the article's Creative Commons licence and your intended use is not permitted by statutory regulation or exceeds the permitted use, you will need to obtain permission directly from the copyright holder. To view a copy of this licence, visit http://creativecommons.org/licenses/by/4.0/.

\section{References}

1. Lyons RM, Moses HL (1990) Transforming growth factors and the regulation of cell proliferation. Eur J Biochem 187:467-473. https://doi.org/10.1111/j.1432-1033.1990.tb15327.x

2. Radin DP, Patel P (2017) BDNF: an oncogene or tumor suppressor? Anticancer Res 37:3983-3990. https://doi.org/10.21873/antic anres. 11783

3. Witsch E, Sela M, Yarden Y (2010) Roles for growth factors in cancer progression. Physiology (Bethesda) 25:85-101. https://doi. org/10.1152/physiol.00045.2009

4. Xiao L, Sharma VK, Toulabi L, Yang X, Lee C, Abebe D, Peltekian A, Arnaoutova I, Lou H, Loh YP (2021) Neurotrophic factor-alpha1, a novel tropin is critical for the prevention of stressinduced hippocampal CA3 cell death and cognitive dysfunction in mice: comparison to BDNF. Transl Psychiatry 11:24. https:// doi.org/10.1038/s41398-020-01112-w

5. Fricker LD, Snyder SH (1983) Purification and characterization of enkephalin convertase, an enkephalin-synthesizing carboxypeptidase. J Biol Chem 258:10950-10955
6. Hook VY, Eiden LE, Brownstein MJ (1982) A carboxypeptidase processing enzyme for enkephalin precursors. Nature 295:341342. https://doi.org/10.1038/295341a0

7. Xiao L, Yang X, Loh YP (2019) Neurotrophic, gene regulation, and cognitive functions of carboxypeptidase E-neurotrophic factor-alpha1 and its variants. Front Neurosci 13:243. https://doi.org/ 10.3389/fnins.2019.00243

8. Woronowicz A, Koshimizu H, Chang SY, Cawley NX, Hill JM, Rodriguiz RM, Abebe D, Dorfman C, Senatorov V, Zhou A, Xiong ZG, Wetsel WC, Loh YP (2008) Absence of carboxypeptidase $\mathrm{E}$ leads to adult hippocampal neuronal degeneration and memory deficits. Hippocampus 18:1051-1063. https://doi.org/10. 1002/hipo. 20462

9. Jin K, Graham SH, Nagayama T, Goldsmith PC, Greenberg DA, Zhou A, Simon RP (2001) Altered expression of the neuropeptideprocessing enzyme carboxypeptidase $\mathrm{E}$ in the rat brain after global ischemia. J Cereb Blood Flow Metab 21:1422-1429. https://doi. org/10.1097/00004647-200112000-00006

10. Cheng Y, Cawley NX, Yanik T, Murthy SR, Liu C, Kasikci F, Abebe D, Loh YP (2016) A human carboxypeptidase E/NF-alpha1 gene mutation in an Alzheimer's disease patient leads to dementia and depression in mice. Transl Psychiatry 6:e973. https://doi.org/ 10.1038/tp.2016.237

11. Durmaz A, Aykut A, Atik T, Ozen S, Ayyildiz Emecen D, Ata A, Isik E, Goksen D, Cogulu O, Ozkinay F (2020) A new cause of obesity syndrome associated with a mutation in carboxypeptidase (CPE) gene detected in three siblings with obesity, intellectual disability and hypogonadotropic hypogonadism. J Clin Res Pediatr Endocrinol. https://doi.org/10.4274/jcrpe.galenos.2020.2020.0101

12. Alsters SI, Goldstone AP, Buxton JL, Zekavati A, Sosinsky A, Yiorkas AM, Holder S, Klaber RE, Bridges N, van Haelst MM, le Roux CW, Walley AJ, Walters RG, Mueller M, Blakemore AI (2015) Truncating homozygous mutation of carboxypeptidase E (CPE) in a morbidly obese female with type 2 diabetes mellitus, intellectual disability and hypogonadotrophic hypogonadism. PLoS ONE 10:e0131417. https://doi.org/10.1371/journal.pone. 0131417

13. Bosch E, Hebebrand M, Popp B, Penger T, Behring B, Cox H, Towner S, Kraus C, Wilson WG, Khan S, Krumbiegel M, Ekici AB, Uebe S, Trollmann R, Woelfle J, Reis A, Vasileiou G (2021) BDV-syndrome: an emerging syndrome with profound obesity and neurodevelopmental delay resembling Prader-Willi syndrome. J Clin Endocrinol Metab. https://doi.org/10.1210/clinem/dgab592

14. Cheng Y, Cawley NX, Loh YP (2013) Carboxypeptidase E/NFalpha1: a new neurotrophic factor against oxidative stress-induced apoptotic cell death mediated by ERK and PI3-K/AKT pathways. PLoS ONE 8:e71578. https://doi.org/10.1371/journal.pone.00715 78

15. Cheng Y, Cawley NX, Loh YP (2014) Carboxypeptidase E (NFalpha1): a new trophic factor in neuroprotection. Neurosci Bull 30:692-696. https://doi.org/10.1007/s12264-013-1430-z

16. Chougule A, Kolli V, Baroi S, Ebraheim N, Czernik PJ, Loh YP, Lecka-Czernik B (2020) Nonenzymatic and trophic activities of carboxypeptidase e regulate bone mass and bioenergetics of skeletal stem cells in mice. JBMR Plus 4:e10392. https://doi.org/10. 1002/jbm4.10392

17. Levy FO, Gudermann T, Birnbaumer M, Kaumann AJ, Birnbaumer L (1992) Molecular cloning of a human gene (S31) encoding a novel serotonin receptor mediating inhibition of adenylyl cyclase. FEBS Lett 296:201-206. https://doi.org/10.1016/00145793(92)80379-u

18. Leonhardt S, Herrick-Davis K, Titeler M (1989) Detection of a novel serotonin receptor subtype (5-HT1E) in human brain: interaction with a GTP-binding protein. J Neurochem 53:465-471. https://doi.org/10.1111/j.1471-4159.1989.tb07357.x 
19. Bai F, Yin T, Johnstone EM, Su C, Varga G, Little SP, Nelson DL (2004) Molecular cloning and pharmacological characterization of the guinea pig 5-HT1E receptor. Eur J Pharmacol 484:127-139. https://doi.org/10.1016/j.ejphar.2003.11.019

20. Bruinvels AT, Landwehrmeyer B, Gustafson EL, Durkin MM, Mengod G, Branchek TA, Hoyer D, Palacios JM (1994) Localization of 5-HT1B, 5-HT1D alpha, 5-HT1E and 5-HT1F receptor messenger RNA in rodent and primate brain. Neuropharmacology 33:367-386. https://doi.org/10.1016/0028-3908(94)90067-1

21. Klein MT, Teitler M (2009) Guinea pig hippocampal 5-HT(1E) receptors: a tool for selective drug development. J Neurochem 109:268-274. https://doi.org/10.1111/j.1471-4159.2009.05958.x

22. Klein MT, Teitler M (2012) Distribution of 5-ht(1E) receptors in the mammalian brain and cerebral vasculature: an immunohistochemical and pharmacological study. Br J Pharmacol 166:12901302. https://doi.org/10.1111/j.1476-5381.2012.01868.x

23. Qin X, Li J, Wang S, Lv J, Luan F, Liu Y, Chen Y, Chen X, Zhao Y, Zhu J, Piao Y, Zhang W, Shi Y, Xiang R, Qu P, Wang L (2021) Serotonin/HTR1E signaling blocks chronic stress-promoted progression of ovarian cancer. Theranostics 11:6950-6965. https:// doi.org/10.7150/thno.58956

24. Kroeze WK, Sassano MF, Huang XP, Lansu K, McCorvy JD, Giguere PM, Sciaky N, Roth BL (2015) PRESTO-Tango as an open-source resource for interrogation of the druggable human GPCRome. Nat Struct Mol Biol 22:362-369. https://doi.org/10. 1038/nsmb.3014

25. Hilger D, Kumar KK, Hu H, Pedersen MF, O’Brien ES, Giehm L, Jennings C, Eskici G, Inoue A, Lerch M, Mathiesen JM, Skiniotis G, Kobilka BK (2020) Structural insights into differences in $\mathrm{G}$ protein activation by family A and family B GPCRs. Science. https://doi.org/10.1126/science.aba3373

26. Ballesteros JA and Weinstein H (1995) [19] Integrated methods for the construction of three-dimensional models and computational probing of structure-function relations in $\mathrm{G}$ protein-coupled receptors. In: Receptor molecular biology, pp 366-428

27. Pandy-Szekeres G, Munk C, Tsonkov TM, Mordalski S, Harpsoe K, Hauser AS, Bojarski AJ, Gloriam DE (2018) GPCRdb in 2018: adding GPCR structure models and ligands. Nucleic Acids Res 46:D440-D446. https://doi.org/10.1093/nar/gkx1109

28. Kim K, Che T, Panova O, DiBerto JF, Lyu J, Krumm BE, Wacker D, Robertson MJ, Seven AB, Nichols DE, Shoichet BK, Skiniotis G, Roth BL (2020) Structure of a hallucinogen-activated Gqcoupled 5-HT2A serotonin receptor. Cell 182(1574-1588):e19. https://doi.org/10.1016/j.cell.2020.08.024

29. Kobilka BK (2007) G protein coupled receptor structure and activation. Biochim Biophys Acta 1768:794-807. https://doi.org/10. 1016/j.bbamem.2006.10.021

30. Yao X, Parnot C, Deupi X, Ratnala VR, Swaminath G, Farrens D, Kobilka B (2006) Coupling ligand structure to specific conformational switches in the beta2-adrenoceptor. Nat Chem Biol 2:417-422. https://doi.org/10.1038/nchembio801

31. Ballesteros JA, Jensen AD, Liapakis G, Rasmussen SG, Shi L, Gether U, Javitch JA (2001) Activation of the beta 2-adrenergic receptor involves disruption of an ionic lock between the cytoplasmic ends of transmembrane segments 3 and 6. J Biol Chem 276:29171-29177. https://doi.org/10.1074/jbc.M103747200

32. Mabuchi T, Kitagawa K, Kuwabara K, Takasawa K, Ohtsuki T, Xia Z, Storm D, Yanagihara T, Hori M, Matsumoto M (2001) Phosphorylation of cAMP response element-binding protein in hippocampal neurons as a protective response after exposure to glutamate in vitro and ischemia in vivo. J Neurosci 21:9204-9213

33. Meller R, Minami M, Cameron JA, Impey S, Chen D, Lan JQ, Henshall DC, Simon RP (2005) CREB-mediated Bcl-2 protein expression after ischemic preconditioning. J Cereb Blood Flow Metab 25:234-246. https://doi.org/10.1038/sj.jcbfm.9600024
34. Schrage R, Schmitz AL, Gaffal E, Annala S, Kehraus S, Wenzel D, Bullesbach KM, Bald T, Inoue A, Shinjo Y, Galandrin S, Shridhar N, Hesse M, Grundmann M, Merten N, Charpentier TH, Martz M, Butcher AJ, Slodczyk T, Armando S, Effern M, Namkung Y, Jenkins L, Horn V, Stossel A, Dargatz H, Tietze D, Imhof D, Gales C, Drewke C, Muller CE, Holzel M, Milligan G, Tobin AB, Gomeza J, Dohlman HG, Sondek J, Harden TK, Bouvier M, Laporte SA, Aoki J, Fleischmann BK, Mohr K, Konig GM, Tuting $\mathrm{T}$, Kostenis E (2015) The experimental power of FR900359 to study Gq-regulated biological processes. Nat Commun 6:10156. https://doi.org/10.1038/ncomms10156

35. Mashukova A, Spehr M, Hatt H, Neuhaus EM (2006) Beta-arrestin2-mediated internalization of mammalian odorant receptors. J Neurosci 26:9902-9912. https://doi.org/10.1523/JNEUROSCI. 2897-06.2006

36. Yang Z, Yang F, Zhang D, Liu Z, Lin A, Liu C, Xiao P, Yu X, Sun JP (2017) Phosphorylation of G protein-coupled receptors: from the barcode hypothesis to the flute model. Mol Pharmacol 92:201-210. https://doi.org/10.1124/mol.116.107839

37. Zhou XE, He Y, de Waal PW, Gao X, Kang Y, Van Eps N, Yin Y, Pal K, Goswami D, White TA, Barty A, Latorraca NR, Chapman HN, Hubbell WL, Dror RO, Stevens RC, Cherezov V, Gurevich VV, Griffin PR, Ernst OP, Melcher K, Xu HE (2017) Identification of phosphorylation codes for arrestin recruitment by $\mathrm{G}$ proteincoupled receptors. Cell 170(457-469):e13. https://doi.org/10. 1016/j.cell.2017.07.002

38. Staus DP, Hu H, Robertson MJ, Kleinhenz ALW, Wingler LM, Capel WD, Latorraca NR, Lefkowitz RJ, Skiniotis G (2020) Structure of the M2 muscarinic receptor-beta-arrestin complex in a lipid nanodisc. Nature 579:297-302. https://doi.org/10.1038/ s41586-020-1954-0

39. Mafi A, Kim SK, Goddard WA 3rd (2020) Mechanism of betaarrestin recruitment by the mu-opioid $\mathrm{G}$ protein-coupled receptor. Proc Natl Acad Sci USA 117:16346-16355. https://doi.org/10. 1073/pnas.1918264117

40. Podvin S, Wojnicz A, Hook V (2018) Human brain gene expression profiles of the cathepsin $\mathrm{V}$ and cathepsin $\mathrm{L}$ cysteine proteases, with the PC1/3 and PC2 serine proteases, involved in neuropeptide production. Heliyon 4:e00673. https://doi.org/10.1016/j. heliyon.2018.e00673

41. Shimron-Abarbanell D, Nothen MM, Erdmann J, Propping P (1995) Lack of genetically determined structural variants of the human serotonin-1E (5-HT1E) receptor protein points to its evolutionary conservation. Brain Res Mol Brain Res 29:387-390. https://doi.org/10.1016/0169-328x(95)00003-b

42. Netter A, Gayral MN, Millet D (1976) The gonadotropic hypothalamus. Its development from the embryonic period to the menopause. J Gynecol Obstet Biol Reprod (Paris) 5:225-246

43. Ryu K, Gilchrist RL, Tung CS, Ji I, Ji TH (1998) High affinity hormone binding to the extracellular $\mathrm{N}$-terminal exodomain of the follicle-stimulating hormone receptor is critically modulated by exoloop 3. J Biol Chem 273:28953-28958. https://doi.org/10. $1074 / j b c .273 .44 .28953$

44. Xie YB, Wang H, Segaloff DL (1990) Extracellular domain of lutropin/choriogonadotropin receptor expressed in transfected cells binds choriogonadotropin with high affinity. J Biol Chem 265:21411-21414

45. Arany I, Megyesi JK, Reusch JE, Safirstein RL (2005) CREB mediates ERK-induced survival of mouse renal tubular cells after oxidant stress. Kidney Int 68:1573-1582. https://doi.org/ 10.1111/j.1523-1755.2005.00569.x

46. Fu X, Feng Y, Shao B, Zhang Y (2019) Activation of the ERK/ $\mathrm{Creb} / \mathrm{Bcl} 2$ pathway protects periodontal ligament stem cells against hydrogen peroxideinduced oxidative stress. Mol Med Rep 19:3649-3657. https://doi.org/10.3892/mmr.2019.10027 
47. Belcheva MM, Coscia CJ (2002) Diversity of G protein-coupled receptor signaling pathways to ERK/MAP kinase. Neurosignals 11:34-44. https://doi.org/10.1159/000057320

48. Lefkowitz RJ, Shenoy SK (2005) Transduction of receptor signals by beta-arrestins. Science 308:512-517. https://doi.org/10.1126/ science. 1109237

49. McAllister G, Charlesworth A, Snodin C, Beer MS, Noble AJ, Middlemiss DN, Iversen LL, Whiting P (1992) Molecular cloning of a serotonin receptor from human brain (5HT1E): a fifth
5HT1-like subtype. Proc Natl Acad Sci USA 89:5517-5521. https://doi.org/10.1073/pnas.89.12.5517

Publisher's Note Springer Nature remains neutral with regard to jurisdictional claims in published maps and institutional affiliations. 